\title{
What were the four Divisions of Middle Chinese?
}

\author{
(updated version)
}

\author{
Michel FERLUS \\ Centre National de la Recherche Scientifique, France
}

The text presented here is the final result of a series of versions of our research on the four divisions (or grades) of ancient Chinese (Middle Chinese) :

1. (1998) Du chinois archaïque au chinois ancien : monosyllabisation et formation des syllabes tendu/lâche (Nouvelle théorie sur la phonétique historique du chinois), The 31st International Conference on Sino-Tibetan Languages and Linguistics, University of Lund, Swiden, Sept. 30th - Oct. 4th (22 pages). (Available: https://halshs.archives-ouvertes.fr/halshs-00927220)

2. (2006) What were the four divisions (děng) of Middle Chinese ?, The 39th International Conference on Sino-Tibetan Languages and Linguistics, University of Washington, Seattle, September 15-17 (12 pages).

3. (2009) What were the four Divisions of Middle Chinese ? Diachronica 26(2): $184-213$.

4. (2014) 中古汉语四等的来龙去脉 Zhōnggǔ Hànyǔ sìděng de láilóngqùmài [Origin and development of the Four Divisions of Middle Chinese / Le pourquoi et le comment des quatre divisions du chinois ancien]. 语言学论从 Yǔyánxué Lùncōng [Bulletin of Linguistics] 49: 312-349. 北京大学 [Beijing University]. This is translation of the third version, enlarged with new paragraphs.

5. The present text is the enlarged version that was translated into Chinese by Professor SHEN Ruiqing 沈瑞清.

Reading guide :

Many thanks to my colleague Alexis Michaud for the care and skill with which he proofread this text and suggested corrections. I remain solely responsible for all decisions on contents and form.

Note: For the sake of clarity the new paragraphs that were added in the version translated into Chinese are indicated in blue. Some pages have blank space at bottom to avoid splitting tables over two pages. 
Determining the nature of the four Divisions of the Qièyùn is a fundamental problem in the study of the phonetic history of Chinese. Analyses by Baxter and Pulleyblank make it possible to bring out two major changes from Old Chinese to Middle Chinese: a two-way split of the vowel system, and later the lenition of medial -r-. The use of models drawn from Mon-Khmer voice type register languages made it possible to reconstruct the phonetic bases of the four divisions. Div. I consists of tense rimes, Div. II consists of tense, velarized rimes resulting from medial -r-, Div. III consists of lax/breathy rimes. As for Div. IV, it consists of (non velarized) rimes with the diphthong ie.

Keywords: Chinese, Middle Chinese, Qièyùn, rimes, Divisions, phonetic history.

The goal of this article is to explain the nature and the diachronic origin of what is known as the four Divisions system of Middle Chinese, and to understand the way this four-way system was elaborated by its authors. The present research uses tools originally developed for minor languages of the Southeast Asian area.

\section{The Chinese document: Rime books and rime tables}

Dictionaries of rimes (rime books) and rime tables are reference books for verse composition. They classify characters according to their rimes (yùn 韻), not their semantic key. Thorough introductions to these books can be found in Norman (1988), Baxter (1992), Coblin (1996), Pulleyblank (1998) and Branner (2006a, 2006b).

\subsection{The Qièyùn, a rime book}

The most famous among rime books is the Qièyùn 切韻, elaborated by Lù Făyán (601 $\mathrm{CE}$ ). Only its preface has been preserved, but its contents survived through a revised version, the Guăngyùn 廣韻 (1007-1008 CE), which is widely used by specialists. It is generally considered that the linguistic system described in the Qièyùn resulted from its authors' efforts to elaborate a standard containing all the distinctions made in the main language varieties of the North and the South.

The Qièyùn is organized into five fascicles (juàn 卷), one for each of the four tones; the level tone occupies two fascicles. Within each fascicle, characters are classified into rime groups (shè 攝) identified by their first character. Within each rime group, characters rhyme - or used to rhyme - with one another. The pronunciation of rare characters is indicated by the method called fãnqiè 反切, which can be translated as "spelling rimes". It consists in spelling a character by means of two other characters, the first of which shares its initial and the second its rime. To take a deliberately simplified example, dong will be spelled as $d(\mathrm{e})+(h)$ ong. 


\subsection{The Yùnjìng, a rime table}

In the 12th century, there appear rime tables, the most famous of which is the Yùnjing 韻鏡, the 'mirror of rimes'. The principle of classification of characters is the same as in the rime books.

The Yùnjìng comprises 43 tables of characters (zhuăn 轉); each table occupies two adjacent pages. Each table consists of a grid of six columns and four rows, i.e. 24 cells. The place of a character is determined by its initial (columns) and rime (rows). Each row corresponds to one of the four tonal groups (sì shēng 四聲); each tonal group is, in turn, divided into four elementary rows corresponding to the four Divisions (sì děng 四等), also called Grades. We will now explain to readers who are not familiar with these sinological data the principles underlying the classification of characters in the Yùnjìng, taking as an example the first page of the first table : see Tables $1 \mathrm{~A}$ and $1 \mathrm{~B}$.

Table $1 \mathrm{~A}$ reproduces the first page of the first table of Yùnjìng. Characters are divided into three columns (the entire table, over two pages, comprises six columns) according to the point and mode of articulation, described in the top cells: from right to left, labials (column framed with a thick line), apicals and velars. Other articulations are shown on the second page, not reproduced here.

Table 1B provides details about the column of labials; it corresponds to the framed column in Table 1A. Characters are indicated in pinyīn transcription, with their restitution in Late Middle Chinese (Pulleyblank 1991). The circle $\bigcirc$ signals the absence of any character of the corresponding composition. The top cell indicates the characteristics of initials, which can be restituted as ${ }^{*} \mathrm{p}-{ }^{*} \mathrm{p}^{\mathrm{h}}{ }^{*}{ }^{*} \mathrm{~b}-{ }^{*} \mathrm{~m}-$ for the Early Middle Chinese stage (i.e. the time of the Qièyùn: 7th century). Importantly, at the time of the Yùnjing, corresponding to Late Middle Chinese, the voiced ${ }^{*} b-$ is described as 'muddy', i.e. is undergoing devoicing, as indicated by the transcriptions $\mathbf{p}^{\mathbf{f}}$ and $\mathbf{f}^{\mathbf{f}}$. Each row, named by a character written in large print (to the left), groups characters of like tone: from top to bottom, these are dōng 東 (level tone), dǒng 董 (rising tone), sòng 送 (departing tone) and $w \bar{u}$ 屋 (entering tone). Each tonal group comprises four lines of characters, corresponding to the four Divisions, numbered I II III and IV. 
Table 1A: First page of the Yùnjìng

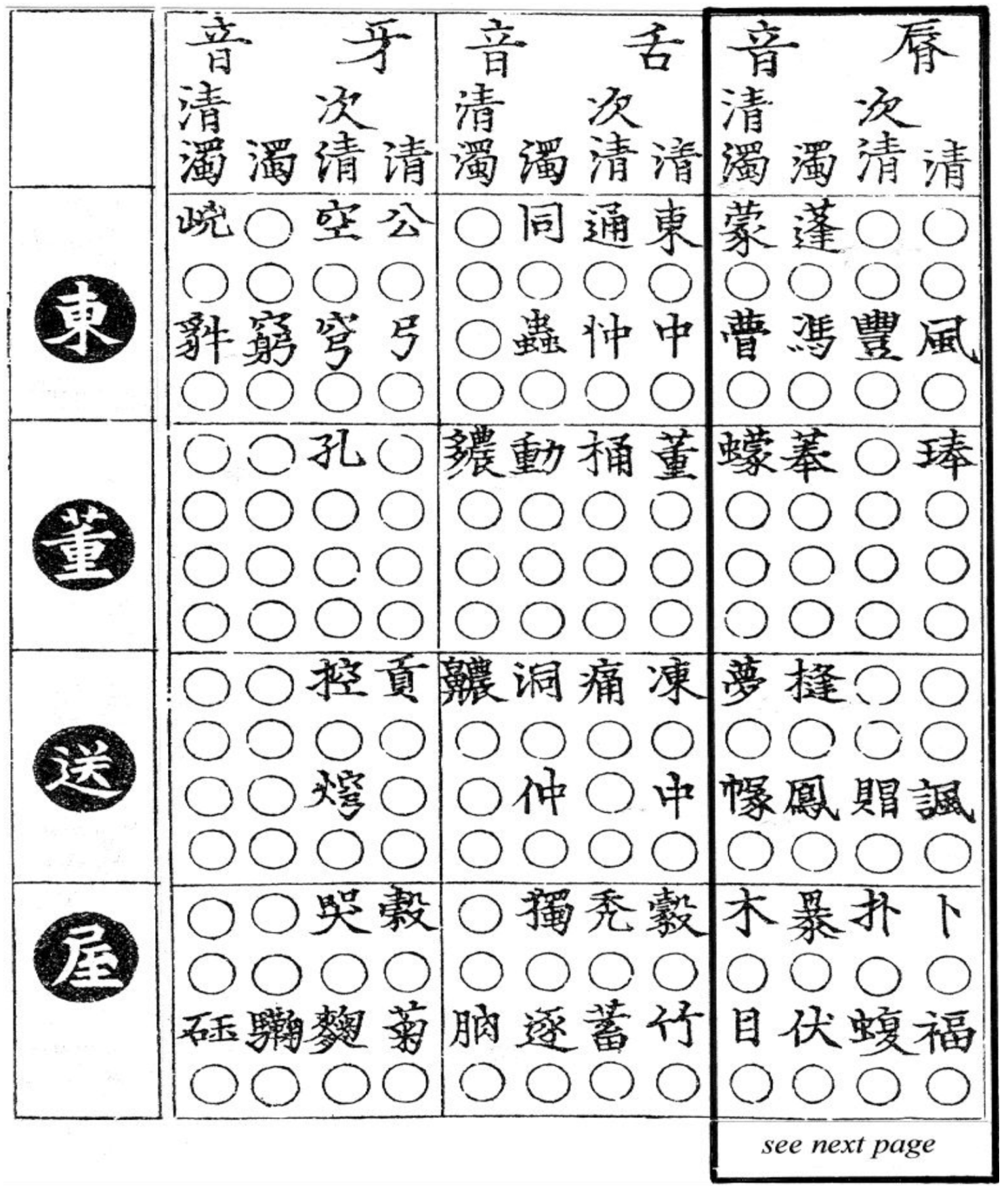


Table 1в : Transcription of the first page of the Yùnjìng (from right to left)

\begin{tabular}{|c|c|c|c|c|c|}
\hline & \multicolumn{4}{|c|}{ LABIAL INITIALS } \\
\hline & & $* \mathrm{~m}-$ & $* b-$ & $* p^{h}-$ & $* \mathrm{p}-$ \\
\hline \multirow{4}{*}{$\begin{array}{l}\text { LEVEL TONE } \\
\text { 東 } \\
\text { dōng } \\
\text { towy }\end{array}$} & I & $\begin{array}{l}\text { méng } \\
\text { məwy }\end{array}$ & $\begin{array}{c}\text { péng } \\
\text { p }^{\text {fं } ә w y}\end{array}$ & O & O \\
\hline & II & $\bigcirc$ & $\bigcirc$ & $\bigcirc$ & $\bigcirc$ \\
\hline & III & $\begin{array}{l}\text { méng } \\
\text { muə̆y }\end{array}$ & $\begin{array}{c}\text { féng } \\
\text { ffiuwy }^{\text {fi }}\end{array}$ & $\begin{array}{l}\text { fēng } \\
\text { fuwy }\end{array}$ & $\begin{array}{l}\text { fēng } \\
\text { fuwy }\end{array}$ \\
\hline & IV & $\bigcirc$ & 0 & 0 & 0 \\
\hline \multirow{4}{*}{$\begin{array}{l}\text { RISING TONE } \\
\frac{\text { 董 }}{\text { dóng }} \\
\text { təwn' }\end{array}$} & I & $\begin{array}{l}\text { měng } \\
\text { məwy' }\end{array}$ & $\begin{array}{l}\text { féng } \\
\text { pəwn' }\end{array}$ & O & $\begin{array}{l}\text { běng } \\
\text { pəwy }\end{array}$ \\
\hline & II & 0 & $\bigcirc$ & $\bigcirc$ & $\bigcirc$ \\
\hline & III & $\bigcirc$ & $\bigcirc$ & $\bigcirc$ & $\bigcirc$ \\
\hline & IV & $\bigcirc$ & $\bigcirc$ & 0 & $\bigcirc$ \\
\hline \multirow{4}{*}{$\begin{array}{l}\text { DEPARTING TONE } \\
\text { 送 } \\
\text { sòng } \\
\text { sown' }\end{array}$} & I & $\begin{array}{l}\text { mèng } \\
\text { məwy }\end{array}$ & $\begin{array}{c}\text { féng } \\
\text { f }^{f} \text { əwy }\end{array}$ & $\bigcirc$ & $\bigcirc$ \\
\hline & II & $\bigcirc$ & $\bigcirc$ & $\bigcirc$ & $\bigcirc$ \\
\hline & III & $\begin{array}{l}\text { mèng } \\
\text { mowy }\end{array}$ & $\begin{array}{l}\text { fèng } \\
\text { fuwy }\end{array}$ & $\begin{array}{l}\text { fèng } \\
\text { fuwy }\end{array}$ & $\begin{array}{l}\text { fèng } \\
\text { fuwn’ }\end{array}$ \\
\hline & IV & $\bigcirc$ & 0 & $\bigcirc$ & $\bigcirc$ \\
\hline \multirow{5}{*}{$\begin{array}{c}\text { ENTERING TONE } \\
\text { 屋 } \\
w \bar{u} \\
\text { Pəwk }\end{array}$} & $\mathrm{I}$ & $\begin{array}{c}\text { mù } \\
\text { mowk }\end{array}$ & $\begin{array}{c}p \grave{u} \\
n^{\mathrm{f}} \partial w k\end{array}$ & $\begin{array}{c}p \bar{u} \\
p^{\mathrm{h}} \partial w \mathrm{w}\end{array}$ & bǔ \\
\hline & II & 0 & $\bigcirc$ & $\bigcirc$ & 0 \\
\hline & & mù & fú & fù & fú \\
\hline & 111 & muwk & $\mathrm{f}^{\text {fi }} \mathrm{uwk}$ & $p^{h} u w k$ & fuwk \\
\hline & IV & $\bigcirc$ & $\bigcirc$ & $\bigcirc$ & $\bigcirc$ \\
\hline
\end{tabular}




\subsection{A long standing puzzle: The meaning of the four Divisions}

Rime books and rime tables have been the object of in-depth studies in China and in the West, aiming to arrive at the pronunciation of Middle Chinese and to understand the phonetic evolution of Chinese. The classical notions of initial, rime and tone have been well identified, but the notion of Division remains opaque. Despite the efforts of talented specialists, no satisfying explanation has been found for the four Divisions. The situation is clearly summarized by Coblin (1996: 350), who says of the four rows corresponding to the four Divisions:

... the phonological significance of the rows is obscure. This is a pity, because if we knew what the rows denoted we might recover fundamental facts about the syllable finals of whatever (if any) linguistic reality underlay the tables. But the simple fact is, we do not know what the four rows in the YJ represented.

A number of theories have been proposed about this; but in the end all these theories are nothing more than speculations.

However, he remarks, on a more optimistic note:

It is conceivable that someday we may discover a contemporary explanation of the rows which would solve the problem.

The present article sets out an explanation which, while based on external evidence building on models developed for Southeast Asian languages - , is actually supported by evidence from contemporary descriptions.

\section{Background}

The results presented here constitute a development of the author's theory (Ferlus 1998) concerning the phenomenon of monosyllabization that occurred between Old Chinese (hereafter OC) and Middle Chinese (hereafter MC). This theory will be used here as a starting point in the explanation of the nature of the four Divisions in the Qièyùn (hereafter QY).

\subsection{From OC to MC: A brief survey}

Old Chinese was a disyllabic language, in the sense that while one part of the vocabulary was monosyllabic, another part was made up of disyllabic words, more precisely of the sesquisyllabic type. This type is still widely represented in many Austroasiatic languages of Southeast Asia.

A sesquisyllable $C . C V(C)$ is a type of disyllable composed of a main syllable $C V(C)$ preceded by a presyllable $C$-. The main syllable is similar to a monosyllabic word, whereas the presyllable is a reduced and unstressed syllable in which vocalic contrasts are neutralized. The presyllable can be a morphological prefix or a neutral element without any meaning.

$$
\begin{array}{rr}
\text { monosyllable: } & \mathrm{CV}(\mathrm{C}) \\
\text { sesquisyllable: } & \mathrm{C} . \mathrm{CV}(\mathrm{C})
\end{array}
$$

OC sesquisyllables developed phonetic tenseness $\left[{ }^{\mathbf{T}}\right.$ ] while monosyllables developed laxness $\left.{ }^{\mathrm{L}}\right]$. Then, when sesquisyllabic words became monosyllabic by the loss of the presyllable, the former contrast of syllabic type, $C . C V(C)$ vs. $C V(C)$, was replaced by a new contrast, tense vs. lax.

In fact, the situation is not as simple, and it is necessary to consider two cases. (a) The formation of tenseness requires that the two initial consonants C.C- of sesqui- 
syllable are in close contact, forming a fused cluster, C.C-. In this case, the coalescence of the inherent tenseness in each consonant developed a high tenseness. (b) If any one element (nasal, trill, schwa, or hiatus) is interposed between the two consonants, it maintains a iambic cluster $\mathrm{C} \partial \mathrm{C}$-, and the coalescence is not possible. In that case the sesqui-syllable behaves as a monosyllable that will develop by contrast a low tenseness, ie a laxness. These notions of 'iambic cluster' and 'fused cluster' are developed in Laurent Sagart (1999).

The formation of tense vs. lax contrast was associated with a vocalic split: vowel lowering occurred in tense syllables, and vowel raising in lax syllables. Moreover, some rimes merged independently in each series.

Some centuries later, in a second step, the velarization of medial -r-, and then its lenition, blurred the situation. This is the stage of MC, characterized by the wellknown, but ill-understood, system of four Divisions: the tense syllables belong to Div. I/IV (syllables without medial -r- in OC) or to Div. II (medial -r- in OC), whereas the lax syllables belong to Div. III (with or without medial $-r$ - in OC), characterized by the famous so-called yod of the reconstructions in Karlgren (1957).

Table 2: Syllables from OC to MC

\begin{tabular}{|c|c|c|}
\hline Old Chinese (OC) & Middle Chinese (MC) & Divisions \\
\hline $\begin{array}{l}\text { C.CV }(\mathrm{C}) \\
\text { (tenseness) }\end{array}$ & $\begin{aligned}> & \mathrm{CV}(\mathrm{C})^{\mathrm{T}} \\
& (\text { vowel lowering) }\end{aligned}$ & $\mathrm{I} / \mathrm{IV}(-\mathbf{r})$ or II $(+\mathbf{r})$ \\
\hline $\begin{array}{l}\mathrm{CV}(\mathrm{C}) \\
\text { (laxness) }\end{array}$ & $\begin{aligned}> & \mathrm{CV}(\mathrm{C})^{\mathrm{L}} \\
& \text { (vowel raising) }\end{aligned}$ & $\mathrm{III}( \pm \mathbf{r})$ \\
\hline
\end{tabular}

In my system the grave accent ['] is the mark of Div. III. It indicates a raising and centralization of the vowel associated with (what I suspect to be) breathy voice.

The symbol $\left.{ }^{\mathrm{y}}\right]$ is the mark of Div. II. It indicates the result of the velarization of OC medial -r-, probably a kind of velar spirant. Thus Div. II is simply an offshoot of Div. I (and IV, below); together these three Divisions continue the former tense category. In lax syllables, the velarization of OC medial $-\mathbf{r}$ - became obscured by the breathiness of the vowel and was lost (more about this process below); there was no split analogous to the one that gave rise to Div. II. Thus the entire lax category is continued intact by Div. III.

No special mark characterizes Divs. I and IV, which are in complementary distribution. The distinction of Div. I and Div. IV was apparently a device to represent the single MC front diphthong.

This theory, briefly summarized in Table 3, will be set out in detail in what follows.

The tense syllables of MC correspond to Pulleyblank's type A, while the lax syllables correspond to his type B (Pulleyblank 1984, 1994). Hereafter, we will use the designations $\mathrm{A}$ and $\mathrm{B}$ to be in agreement with common practice in present-day sinology.

In Table 3 and elsewhere, we refer to the reconstructions of Baxter's authoritative book (1992), despite the fact that its author has since brought significant modifications to his reconstruction system. We add the IPA equivalent of some of his reconstructions in brackets. 
Table 3: Proposed origins of MC Divisions

\begin{tabular}{|ccc|cc|}
\hline \multicolumn{2}{|c|}{ OC syllable-type } & $\begin{array}{c}\text { OC medial } \\
\text { (Baxter 1992) }\end{array}$ & \multicolumn{2}{|c|}{ MC Division } \\
\hline Sesquisyllable & & (type $A)$ \\
(without medial -r-) & tense & - & I/IV & T \\
(with medial -r-) & tense & $-\mathrm{r}-$ & II & T(r) \\
\hline Monosyllable & & & (type B) \\
(without medial -r-) & lax & $-\mathrm{j}-$ & III & $\mathrm{L}$ \\
$($ with medial -r-) & lax & $-\mathrm{rj}-$ & III & $\mathrm{L}(\mathrm{r})$ \\
\hline
\end{tabular}

\subsection{Periodization}

OC is defined as the stage of the rhyming texts of the Odes, Shijing 詩經 (6th century $\mathrm{BCE})$. However, these texts were only passed on to us in a late version, probably from the beginning of the Han dynasty, and at that time the rimes were updated. Works of the sinologists are based on this version. The $\mathrm{MC}$ is, by definition, the stage of the QY (see §1.1).

The two great phonetic changes, two-way split of the vowel system and velarization of medial -r-, occurred during the period between $\mathrm{OC}$ and $\mathrm{MC}$. Chinese transcriptions of foreign words make it possible to date the changes, in a rather satisfactory way, by applying the rules of reconstruction worked out by Baxter to the characters used in these transcriptions.

- The double change OC -1-> MC d- (in tense syllables, type A) and OC 1-> $\mathrm{MC} \mathbf{j}$ - (in lax syllables, type B) occurred at the same time as the vocalic split. Chinese transcriptions of Yamato and Alexandria, attested in the Hòu Hàn-shu (History of the later Hàn), show that these first changes were under way at the beginning of the 2nd century CE (Pulleyblank 1962: 116-117, Sagart 1999: 31, Yakhontov 1986).

(i) Yamato: xié/yé-mă-tái 邪馬臺 (臺 is now replaced by 台). The last character tái 臺 $<M C$ doj $<\mathrm{OC} *$ li shows that the change $-1->\mathrm{d}-$ is accomplished.

(ii) Alexandria: wū-yì-shān-lí 鳥七山離. The second character yì 七 $<\mathrm{MC}$ yik $<$ OC * $1 \mathrm{jik}$ [1ik $]$ shows that the change $1->\mathrm{j}$ - is not yet accomplished.

- Chinese transcriptions of Sanskrit words, brahma, śrī and Śreșthavarman, concerning ancient Cambodia, show that the softening of the medial -r- took place approximately in the 4th century CE (Ferlus 2005).

According to Nán Qí-shū (History of the Southern Qí), which relates events of the time of $\mathrm{Wu}(222-280 \mathrm{CE})$ concerning the Fu-nan / fú-nán 扶南, i.e. ancient Cambodia, the first sovereign of this country, Fan Che-man / fân-shī-màn 范師蔓, would have reigned about the middle of the 3rd century CE. The first two characters transcribe Sanskrit terms having an initial group with -r-.

(iii) Brahma: fân 范 $<\mathrm{MC}$ bjom $^{\mathrm{X}}<\mathrm{OC} *$ brjom $^{2}\left[\right.$ brəm $\left.^{2}\right]$

(iv) Śrī: shī 師 < MC srij < OC *srjij [sri:]

The Sòng-shū (History of Song) and Nán Liáng-shū (History of the Southern Liang) report the sending of an embassy between 434 and 438 by a king of Fu-nan named Tch'e-li-t'o-pa-mo / chí-lí-tuó-bá-mó 持棨陀跋摩 (Pelliot 1903: 255, 269). This name has been identified as Śreșthavarman (Cœdès 1948: $97 /$ 1989: 110). The first 
syllable, śres-, was transcribed with two characters, which demonstrates clearly that by that time the Chinese language did not have a medial -r- anymore.

\subsection{Documentation on which this study is based}

This study is mainly based on (i) Baxter, A Handbook of Old Chinese Phonology (1992), (ii) Pulleyblank, Lexicon of Reconstructed Pronunciation in Early Middle Chinese, Late Middle Chinese and Early Mandarin (1991) and (iii) Karlgren, Grammata Serica Recensa (1957). The thesis of Handel, The Medial Systems of Old Chinese and Proto-Sino-Tibetan (1998) was very useful. These books were consulted because they are usable by the non-sinologist.

As for the remarkable volume edited by Branner (2006a), The Chinese Rime Tables, the majority of the articles that it contains follow - quite understandably - the traditional method of the sinologist philologists, rather than the properly linguistic point of view adopted here. However, Schuessler (2006) parallels our concerns very closely, as will become apparent below.

\subsection{General theory of the changes associated with 'registrogenesis'}

Although it is not the central subject of this article, it is useful to present an attempt at a unified theory of the phenomena known as 'registral'.

In the languages of Southeast Asia, in particular the Mon-Khmer languages, it is now well established and commonly accepted by specialists, that the cause of registral changes is the devoicing of the voiced initial obstruents and their merger with the voiceless ones (and in parallel, to the revoicing of the voiceless resonants and their merger with the voiced ones). The cause of the changes would thus reside in a tense vs. lax contrast among the initial consonants. However, modern phonetic analyses show that a certain tenseness is associated with the voiceless feature, while a laxness is associated with the voiced feature. The contrast between voiceless and voiced contains a latent, potential contrast between tenseness and laxness (Hombert, Ohala \& Ewan 1979). This clarification makes it possible to establish a linkage between the changes reconstructed in Old Chinese and the changes observed in certain present-day languages of Southeast Asia, known as 'voice type register languages'.

Table 4 connects (i) the facts of type A in Chinese with the facts of high series in some languages of Southeast Asia, and (ii) the facts of the type B with the facts of the low series.

Table 4: Diagram of the changes associated with 'registrogenesis' depending on type A (tense) or B (lax)

\begin{tabular}{|c|c|c|c|c|c|c|}
\hline \multicolumn{2}{|c|}{} & \multicolumn{2}{|c|}{ Chinese OC $>$ MC } & \multicolumn{3}{c|}{ voice type register languages } \\
\cline { 2 - 7 } & initials & Divisions & initials & pitch & \multicolumn{2}{c|}{ vowels } \\
\hline A & C.C- $>$ C- & I/IV II & voiceless & high & lowering & clear \\
\hline B & C- $>$ C- & III & voiced & low & raising & breathy \\
\hline
\end{tabular}

It is clear that the origin of these types of changes are to be sought in a primordial tense vs. lax contrast which is inherent to the voiceless vs. voiced contrast in initials.

Since Karlgren's famous theory of the yod, one now outdated but influential in its time, many other attempts to decipher the sound changes of Chinese according to the 
QY have seen the light. It is not our aim to present them all here, but it is useful to review Norman's hypothesis of pharyngealization in Early Chinese (1994). This author distributed divisions of the QY in three classes. Class A includes the syllables of Div. I and IV and shows a tendency to vocalic lowering. Class B includes syllables of Div. II and syllables of Div. III with retroflex initials. Class $\mathrm{C}$ includes the syllables of Div. III and shows the beginning of palatalization. The vowel lowering in Class A led Norman to propose the phenomenon of pharyngealization on the model of the Semitic languages. For the first time in sinology, a kind of tenseness was invoked to explain the categories of the QY. In spite of the divergences between Norman's approach and the one proposed here, one must stress the meeting point between the two theories, that of Norman (1994) based on internal reconstruction, and mine using an external model drawn from Mon-Khmer languages. According to my view, the phenomenon which Norman describes as pharyngealization must be different from the well-known phenomenon of pharyngealization in Semitic. In Mon-Khmer, as also in the past states of the Chinese language which are the object of the present study, this tenseness formed part of a set of phonetic features found in the tense series which were transitional and short-lived, while in Semitic the pharyngealization has had a considerably longer life-span.

\subsection{Short outline of registro/tonogenesis in Chinese}

In East and Southeast Asia, three processes leading up to the development of suprasegmental features can be brought to light: (i) formation of tones by the loss of syllable-final laryngeals; (ii) formation of phonation type registers as a consequence of the merger of series of initials; and (iii) formation of tones, likewise following the merger of series of initials. The Chinese language can be used to illustrate all three processes.

\subsubsection{Tonogenesis by final laryngeals}

The loss of final laryngeals, first $-\mathbf{P}$ then $-\mathrm{h}$ (and also $-\mathrm{h}<-\mathrm{s}$ ), generates by phonological compensation a system with three tones, one corresponding to each type of laryngeal plus one corresponding to syllables which were open in the first place. One owes to Haudricourt $(1954 a, 1954 b)$ the description of this process of tonogenesis by loss of final laryngeals.

In Chinese, this process led to the formation of three MC tones: píngshēng 平聲 "level tone" (voiced finals); shăngshēng 上聲 “rising tone" (final $-?$ and glottalized sonorants); qùshēng 去聲 "departing tone" (final $-\mathrm{h}$ ). The names of the tones were fixed by Shěn Yue 沈約 and Zhoū Yóng 周颙 at the beginning of the 6th century (Baxter 1992: 303).

It is clear that the denominations píng and shăng refer to the melody. On the other hand, qù 去 “to go away, to depart", like its congeneric words $q \bar{u}$ 祛 "to drive away, to disperse" and $q \bar{u}$ 呿 “to breathe with open mouth", suggest the idea of expulsion rather than that of melody. Our interpretation is that the description qùsheng describes the final spirant $-\mathrm{h}$; this implies that the process of tonogenesis by loss of the finals was not yet completed at the beginning of the 6th century.

The rùshēng 入聲 “entering tone” developed only much later, following the loss of final $-\mathrm{p}-\mathrm{t}-\mathrm{k}$. 


\subsubsection{Registrogenesis by initials}

The concept of voice type register was initially applied to the vowel system of modern Mon (Jenner 1974), although illustrations of register were first published by Henderson (1952), concerning Khmer, and then by Shorto (1962: introduction), concerning Mon.

The development of the tense vs. lax contrast, underlying the voiceless vs. voiced contrast of initials, causes a split of the vocalic system, resulting in the formation of two new vocalic systems: (i) one composed of vowels pronounced on a tense-clearhigh register with a tendency to vowel lowering, (ii) the other formed of vowels on a lax-breathy-low register with a tendency to vowel raising. There are cases where two original vowels of close aperture merge under one register while remaining distinct under the other. All these facts are widely attested in Mon-Khmer languages, where they have been the object of numerous converging observations. Attempts at synthesis concerning these crucial issues of registrogenesis in the languages of Southeast Asia have been published by several scholars, among them Gregerson (1976), Huffman (1976), Ferlus (1979: this study needs to be corrected and updated; the author advises the reader to overlook paragraphs 14-17), Theraphan (1988). The founder article, however, is indisputably that written by Henderson (1952).

In view of this wealth of evidence on the workings of registrogenesis, it appears very clearly that what the QY describes indirectly through the four Divisions system is none other than an instance of registrogenesis. The sole difference lies in the origin of the registrogenesis phenomena: the MC tense vs. lax contrast has its origin in the OC contrast between the complex initials of sesquisyllables C.CV(C), and the simple initials of monosyllables $\mathrm{CV}(\mathrm{C})$ : tenseness in sesquisyllables and laxness in monosyllables. Such is the theory set out in the present article. MC, which thus became a monosyllabic language, underwent a stabilization of the vocalic differences in aperture which are known to be present in registrogenesis. However, later diachronic evolutions, which are not part of registrogenesis proper, such as the velarization of the medial -r- and the chóngniǔ phenomenon, blurred the general picture, which may have contributed to postponing the discovery of this important evolution.

Registrogenesis in MC, described in the QY, must have taken place over a span of time from about the 2 nd century CE to the 4th or 5 th century. It is thus approximately contemporary with tonogenesis by final laryngeals. 


\subsubsection{Tonogenesis by initials}

Tonogenesis by the merging of initial series can be seen as a particular case of registrogenesis in which the language would stabilize by retaining only tonal features, viz. relative levels of fundamental frequency and contours of fundamental frequency. All attested cases of tonogenesis in Far Eastern Asia (e.g. in Chinese dialects, TaiKadai languages, Vietic languages) have their origin in a voiceless vs. voiced contrast of initials. These processes of tonogenesis are by now well-known and welldocumented, see Haudricourt (1954a, 1961), Matisoff (1973) and Mazaudon (1977).

In Late Middle Chinese (Táng period), voiced initial plosives were devoiced into voiceless aspirates or non-aspirates. Chinese dialects combine both solutions depending on the tone at issue. In Pekinese, voiced plosives are devoiced as voiceless aspirated plosives $\left(\mathbf{b}>\mathbf{p}^{\mathbf{h}}, \ldots\right)$ in the píng tone, and as voiceless non-aspirated plosives $(b>p, \ldots)$ in other tones. At the beginning of the 20th century, Maspero (1912:13-19) had already noticed that voiceless and voiced plosives were both transcribed by voiceless ones in the Japanese Kan'on. In descriptions of the time of Sòng, voiceless initial plosives are described as qīng 清 'clear' while voiced ones are zhuó 濁 'muddy'. Pulleyblank (1970-1971: 211-212) thinks that this term meant an acoustic quality other than 'voiced'. To us, there can be no doubt that it was the phonetic feature 'breathy'. A further hint to this effect is that these 'muddy' voiced consonants were used to transcribe the so-called voiced aspirates $b h, d h, g h$ of Sanskrit.

One can place this tonogenetic process in Chinese somewhere between the 8th and 11 th centuries.

\section{The changes from $\mathrm{OC}$ to $\mathrm{MC}$ according to Baxter}

Old Chinese coda system (interpretation of Baxter 1992)

$$
\begin{array}{llll}
-\mathrm{p} & -\mathrm{t} & -\mathrm{k} & -\mathrm{?} \\
-\mathrm{m} & -\mathrm{n} & -\mathrm{y} & \\
-\mathrm{w} & -\mathrm{j} & & -\#
\end{array}
$$

Remarks: The coda $-\mathbf{P}$ is a matter of discussion. The coda -wk is not taken into account. In a further study, a coda -r was introduced (Baxter 1995).

For the sake of our demonstration, we shall select our examples among the rimes in $-\mathbf{n}$ ending grouped in Table 5.1, and among the rimes ending in vowel grouped in Table 5.2. Baxter's transcriptions are respected. 
Table 5.1 : From OC to MC (according to Baxter): rimes ending in $-\mathbf{n}$

\begin{tabular}{|c|c|c|c|c|c|c|}
\hline \multirow[t]{2}{*}{1} & \multirow[t]{4}{*}{2} & \multicolumn{3}{|c|}{3} & 5 & 6 \\
\hline & & \multicolumn{3}{|c|}{$\mathrm{MC}<* \mathrm{OC}$ (without $-\mathrm{r}-$ ) } & \multicolumn{2}{|c|}{$\mathrm{MC}<* \mathrm{OC}$ (with -r-) } \\
\hline \multirow[t]{2}{*}{$\mathrm{OC}$} & & \multicolumn{2}{|c|}{$* \mathrm{OC}(-)$} & $* O C(-j-)$ & $* \mathrm{OC}(-\mathrm{r}-)$ & *OC (-rj-) \\
\hline & & \multicolumn{2}{|c|}{$\mathrm{A}(\mathrm{I} / \mathrm{IV})$} & B (III/III-4) & A (II) & B (III) \\
\hline \multirow{3}{*}{$-(\mathrm{r})$ an } & $\mathrm{P}$ & \multicolumn{2}{|l|}{-an } & -jon & \multirow{3}{*}{-æn } & \multirow{3}{*}{-jen } \\
\hline & $\mathrm{T}$ & \multirow{2}{*}{\multicolumn{2}{|c|}{$\begin{array}{l}\text {-an } \\
\text {-an }\end{array}$}} & \multirow{2}{*}{$\begin{array}{l}\text {-jen } \\
\text {-jon }\end{array}$} & & \\
\hline & $\mathrm{K}$ & & & & & \\
\hline \multirow{3}{*}{$-(r)$ in } & $\mathrm{P}$ & -en & IV & -jin III-4 & \multirow{3}{*}{$-\varepsilon n$} & \\
\hline & $\mathrm{T}$ & -en & IV & -in & & -in \\
\hline & $\mathrm{K}$ & -en & IV & III-4 & & \\
\hline \multirow{3}{*}{$-(r)$ en } & $\mathrm{P}$ & -en & IV & -jien III-4 & \multirow{3}{*}{$-\varepsilon n$} & \multirow{3}{*}{-jen } \\
\hline & $\mathrm{T}$ & -en & IV & -jen & & \\
\hline & $\mathrm{K}$ & -en & IV & -jien III-4 & & \\
\hline \multirow{3}{*}{$-(r)$ in } & $\mathrm{P}$ & \multicolumn{2}{|l|}{-won } & -jun & \multirow{3}{*}{$-\varepsilon n$} & \multirow{3}{*}{-in } \\
\hline & $\mathrm{T}$ & & IV & -in & & \\
\hline & $\mathrm{K}$ & -on & & $-\mathrm{jin}$ & & \\
\hline \multirow{3}{*}{$-(\mathrm{r})$ un } & $\mathrm{P}$ & \multicolumn{2}{|l|}{-won } & -jun & \multirow{3}{*}{-wen } & \multirow{3}{*}{-win } \\
\hline & $\mathrm{T}$ & -won & & -win & & \\
\hline & $\mathrm{K}$ & -won & & -jun & & \\
\hline \multirow{3}{*}{$-(r)$ on } & $\mathrm{P}$ & -wan & & -jwon & \multirow{3}{*}{-wæn } & \multirow{3}{*}{-jwen } \\
\hline & $\mathrm{T}$ & -wan & & -jwen & & \\
\hline & $\mathrm{K}$ & -wan & & -jwon & & \\
\hline
\end{tabular}

- Column 1: OC Rimes.

- Column 2: Capitals P T K indicate the rows of OC initials: P (labials $\mathbf{p}, \mathbf{p}^{\mathbf{h}}, \mathbf{b}$, $\mathrm{m}$ ), $\mathrm{T}$ (dental plosives $\mathrm{t}, \mathrm{t}^{\mathrm{h}}, \mathbf{d}, \mathrm{n}$, dental sibilants $\mathrm{ts} \mathbf{t s}^{\mathrm{h}}, \mathbf{d z}, \mathbf{s}, \mathbf{z}$, trill $\mathrm{r}$ and lateral $\mathbf{1}$ ), $\mathrm{K}$ (velars $\mathbf{k}, \mathbf{k}^{\mathrm{h}}, \mathbf{g}, \mathfrak{\mathbf { y }}, \boldsymbol{\chi}$, and laryngeals $\left.\mathbf{h}, \mathbf{2}\right)$. To simplify, labiovelars $\mathrm{K}^{\mathbf{w}}$ are not taken into account.

- Columns 3-6: The resultant rimes in $\mathrm{MC}$ according to two crossed criteria, presence or absence of the medial -r- in OC, and syllabic type A (tense) or B (lax) in $\mathrm{MC}$.

- Note that in columns 5-6 the rimes are indicated only on the line of apicals T. Since medial -r- is an acute consonant, the clusters $\mathrm{Pr}, \mathrm{Tr}$ and $\mathrm{Kr}$ all act as acute initials on the rimes. 
Table 5.2 : From OC to MC (according to Baxter): rimes ending by a vowel

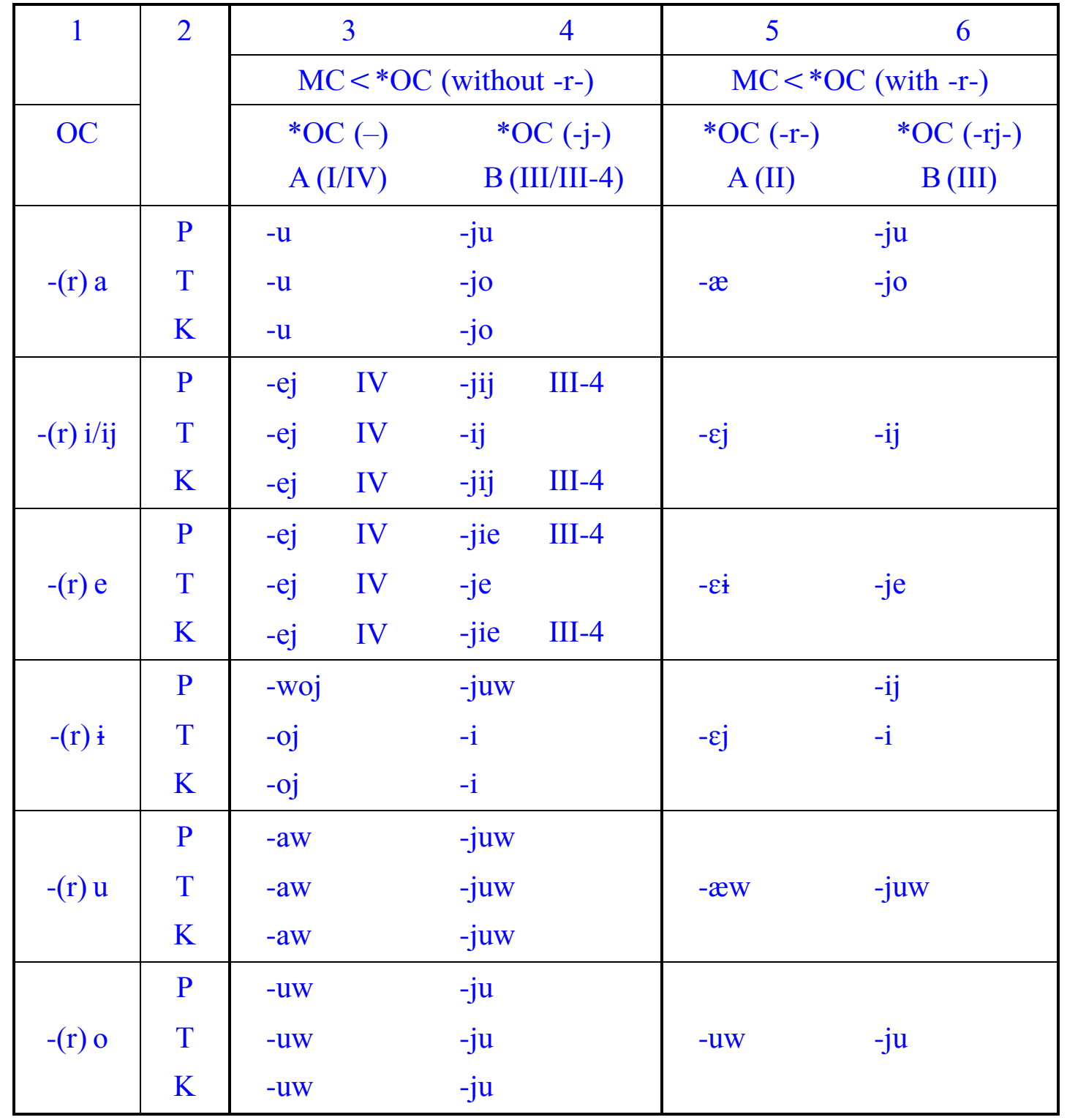

A first examination of Tables 5.1 and 5.2 already gives a general idea of the changes from $\mathrm{OC}$ to $\mathrm{MC}$ : in type $\mathrm{A}$ (columns 3 and 5) a general tendency to vowel lowering (retraction for OC a), in type B (columns 4 and 6) a tendency to vowel raising, and mergers of rimes independently in every type. These phenomena are explored in the following paragraphs. 


\section{On the evidence for a hypothetical first system in two Divisions}

4.1 We believe, according to the theory developed here, that a system with two divisions have existed, because it is an essential step in the sequence of phonetic changes that lead from OC to MC. This system has never been described, probably never even conceived by the Chinese philologists.

\subsubsection{From OC (without medial -r-) to MC: rimes ending in $-\mathbf{n}$}

Table 6.1 (below) contains only the rimes $\mathrm{MC}<\mathrm{OC}$ ending in $-\mathrm{n}$. It represents a reinterpretation of columns 3-4 of Table 5.1. In each type, the rimes are given according to three transcriptions: Baxter (1992), Pulleyblank (see Handel 1998) and my phonetic interpretation, for which I alone am responsible.

The two-way split of the OC vowel system yielded two systems in MC: a system of tense vowels (type A) showing a tendency to lower vowels, and a system of lax vowels (type B) showing a tendency to raise vowels. This type of phenomenon is currently observable in many voice type register languages of the Mon-Khmer family in Southeast Asia.

The two-way split of the OC vocalic system seems to have been completed no earlier than the beginning of the second century of our era (see §2.2). This state is reflected in Table 6.1, but it should be well noted that this table was elaborated according to the situation described in the QY, that is to say six centuries later, itself known through the Guăngyùn. Because of this major chronological gap, there are some difficulties in reconstructing the genuine primary table. We can nonetheless formulate some observations:

- In the syllables of type A, the rime -ien (column 5), mark of the future Div. IV, was still -en, not yet diphthongized.

- In type B, the yod was eliminated as a medial. Moreover Karlgren (1957: 4) has never actually considered the yod, which he transcribes $-i$-, as a medial but as a "subordinate vowel(s) in diphthongs and triphthongs".

- The vowels of type B are presumed to be breathy.

- The medial - $r$ - is an acute consonant. As a consequence the rimes with initial clusters $\mathrm{Pr}, \mathrm{Tr}$ or $\mathrm{Kr}$ changed in the same way as the rimes with acute initial $\mathrm{T}$.

- Vocalic splitting is never regular, no more in Mon-Khmer languages than in Chinese. From the six vowels of OC, one would expect in theory twelve new vowels in $\mathrm{MC}$, six in type $\mathrm{A}$ and six in $\mathrm{B}$. In fact, $\mathrm{MC}$ reconstructions show five $A$ rimes and eight $B$ rimes in the context of final $-n$. In type $A$, there was a merger of $\mathrm{OC}$ rimes -in and -en. In type $\mathrm{B}$, the changes depend on the types of initials, particularly with $\mathrm{OC}$ rime -in. 
Table 6.1 : From OC (without medial -r-) to MC: rimes ending in -n

\begin{tabular}{|c|c|c|c|c|c|c|c|c|c|}
\hline 1 & 2 & 3 & 4 & \multicolumn{2}{|l|}{5} & 6 & \multicolumn{3}{|c|}{8} \\
\hline $\mathrm{OC}$ & & \multicolumn{4}{|c|}{ MC (type A) } & \multicolumn{4}{|c|}{ MC (type B) } \\
\hline Baxt. & & Baxt. & Pull. & Ferlus & & Baxt. & Pull. & Ferlus & \\
\hline \multirow{3}{*}{-an } & $\mathrm{P}$ & -an & -an & -an & I & -jon & -ian & -ì̀n & III \\
\hline & $\mathrm{T}$ & -an & -an & -an & I & -jen & -ian & -ièn & III \\
\hline & $\mathrm{K}$ & -an & -an & -an & I & - jon & $-\tan$ & -ì̀n & III \\
\hline \multirow{3}{*}{-in } & $\mathrm{P}$ & -en & $-\varepsilon n$ & -ien & IV & - jin & -jin & -j-ìn (<-ìn) & III-4 \\
\hline & $\mathrm{T}$ & -en & $-\varepsilon n$ & -ien & IV & -in & -in & -ìn & III \\
\hline & $\mathrm{K}$ & -en & $-\varepsilon n$ & -ien & IV & $-\mathrm{jin}$ & $-\mathrm{jin}$ & -j-ìn $(<-$ ìn$)$ & III-4 \\
\hline \multirow{3}{*}{-en } & $\mathrm{P}$ & -en & $-\varepsilon n$ & -ien & IV & -jien & -jien & -j-ièn $(<-$ ièn $)$ & III-4 \\
\hline & $\mathrm{T}$ & -en & $-\varepsilon n$ & -ien & IV & -jen & -ian & -ièn & III \\
\hline & $\mathrm{K}$ & -en & $-\varepsilon n$ & -ien & IV & -jien & -jien & -j-ièn $(<-$ ièn $)$ & III-4 \\
\hline \multirow{3}{*}{- in } & $\mathrm{P}$ & -won & -wən & -wən & I & -jun & -un & -ùn & III \\
\hline & $\mathrm{T}$ & -en & $-\varepsilon n$ & -ien & IV & -in & -in & -ìn & III \\
\hline & $\mathrm{K}$ & -on & $-\partial n$ & -ən & I & $-\mathrm{jin}$ & -in & -in & III \\
\hline \multirow{3}{*}{-un } & $\mathrm{P}$ & -won & -wən & -wən & I & -jun & -un & -ùn & III \\
\hline & $\mathrm{T}$ & -won & -wən & -wən & I & -win & -win & -uìn & III \\
\hline & $\mathrm{K}$ & -won & -wən & -wən & I & -jun & -un & -ùn & III \\
\hline \multirow{3}{*}{-on } & $\mathrm{P}$ & -wan & -wan & -wan & I & -jwon & -uan & -uòn & III \\
\hline & $\mathrm{T}$ & -wan & -wan & -wan & I & -jwen & -wian & -uèn & III \\
\hline & $\mathrm{K}$ & -wan & -wan & -wan & I & -jwon & -uan & -uòn & III \\
\hline
\end{tabular}


4.1.2 From OC (without medial -r-) to MC: rimes ending in vowel

Table 6.2 (below) contains only the rimes $\mathrm{MC}<\mathrm{OC}$ ending in vowel (without medial -r-). It represents a reinterpretation of columns 3-4 of Table 5.2. Remarks and comments are similar to thoses in Table 6.1.

- In the syllables of type A, the rime -iej (mark of the future Div. IV), column 5, was still -ej, not yet diphthongized.

- In type B, the yod was eliminated as a medial.

- The vowels of type B are presumed to be breathy.

Table 6.2: From OC (without medial -r-) to MC: rimes ending in vowel.

\begin{tabular}{|c|c|c|c|c|c|c|c|c|c|}
\hline 1 & 2 & 3 & 4 & \multicolumn{2}{|l|}{5} & 6 & 7 & \multicolumn{2}{|l|}{8} \\
\hline \multicolumn{2}{|l|}{$\mathrm{OC}$} & \multicolumn{4}{|c|}{ MC (type A) } & \multicolumn{4}{|c|}{ MC (type B) } \\
\hline \multicolumn{2}{|l|}{ Baxt. } & Baxt. & Pull. & \multicolumn{2}{|c|}{ Ferlus } & Baxt. & Pull. & \multicolumn{2}{|l|}{ Ferlus } \\
\hline \multirow{3}{*}{$-\mathrm{a}$} & $\mathrm{P}$ & $-u$ & -כ & -0 & I & $-j u$ & -wuă & -ià & III \\
\hline & $\mathrm{T}$ & $-\mathrm{u}$ & -0 & -0 & I & - jo & $-\grave{i a ̆}$ & -ì̀ & III \\
\hline & $\mathrm{K}$ & $-\mathrm{u}$ & -0 & $-\mathrm{O}$ & I & -jo? & $-\check{\imath} \breve{\partial}$ & -ł̇̀ & III \\
\hline \multirow{3}{*}{$-\mathrm{i} / \mathrm{ij}$} & $\mathrm{P}$ & -ej & $-\varepsilon j$ & $-i e j$ & IV & $-\mathrm{jij}$ & $-\mathrm{ji}$ & $-\mathrm{j}-\mathrm{ijj}(<-\mathbf{i j})$ & III-4 \\
\hline & $\mathrm{T}$ & -ej & $-\varepsilon j$ & -iej & IV & $-\mathrm{ij}$ & $-\mathrm{i}$ & $-i ̀ j$ & III \\
\hline & $\mathrm{K}$ & -ej & $-\varepsilon j$ & -iej & IV & $-\mathrm{jij}$ & $-\mathrm{ji}$ & -j-ìj (<-ìj) & III-4 \\
\hline \multirow{3}{*}{$-e$} & $\mathrm{P}$ & -ej & $-\varepsilon j$ & -iej & IV & $-\mathrm{jie}$ & $-\mathrm{jiă/ji}$ & -j-iè $(<-$-iè $)$ & III-4 \\
\hline & $\mathrm{T}$ & -ej & $-\varepsilon j$ & $-i e j$ & IV & - -je & $-i \breve{\partial} / \mathrm{i}$ & -iè & III \\
\hline & $\mathrm{K}$ & -ej & $-\varepsilon j$ & -iej & IV & - jie & $-\mathrm{jiă/ji}$ & $-j$-iè $(<-i e ̀)$ & III-4 \\
\hline \multirow{3}{*}{$-\dot{i}$} & $\mathrm{P}$ & -woj & $-\partial j$ & $-\partial j$ & I & -juw & $-u w$ & -ùw & III \\
\hline & $\mathrm{T}$ & $-o j$ & $-\partial j$ & $-\partial j$ & IV & $-\mathrm{i}$ & $-\dot{\mathrm{i}} / \mathbf{i}$ & $-\ddot{\mathrm{i} j}$ & III \\
\hline & $\mathrm{K}$ & $-o j$ & $-\partial j$ & $-\partial j$ & I & $-\mathrm{i}$ & $(-\mathbf{i} / \mathbf{i})$ & $-\ddot{i j j}$ & III \\
\hline \multirow{3}{*}{$-\mathrm{u}$} & $\mathrm{P}$ & -aw & $-a w$ & -aw & I & -juw & $(-\mathrm{uw})$ & -ùw & III \\
\hline & $\mathrm{T}$ & -aw & $-a w$ & -aw & I & -juw & $-u w$ & -ùw & III \\
\hline & $\mathrm{K}$ & -aw & $-\mathrm{aw}$ & -aw & I & -juw & -uw & -ùw & III \\
\hline \multirow{3}{*}{-0} & $\mathrm{P}$ & -uw & - & $-כ w$ & I & $-j u$ & -uə̆ & -ùə & III \\
\hline & $\mathrm{T}$ & -uw & $-\partial W$ & $-\partial W$ & I & $-j u$ & -uə̆ & -ùə & III \\
\hline & $\mathrm{K}$ & -uw & $-\partial W$ & $-\partial W$ & I & $-j u$ & -uə̆ & -ùə & III \\
\hline
\end{tabular}

4.1.3 At this point, I have to mention the velarization of medial -r- which occurred approximately four centuries later than the vocalic split, and which is the origin of the formation of a new paradigm of rimes. As I shall set out in detail further on in this article (see §5.1), the new rimes of type A became different from the former rimes of the same type. On the other hand, in type B, the formation of new rimes did not take place. This made the overall picture somewhat opaque and hence delayed the 
discovery of the diachronic sequence of events. To avoid confusion with new B rimes formed later, the old $\mathrm{B}$ rimes resulting from $\mathrm{OC}-\mathbf{i} /-\mathrm{e}$ after grave initials were lengthened by the insertion of $-\mathrm{j}$ - (a true medial). In the rime tables, these lengthened rimes were transferred from Div. III into Div. IV (noted III-4 in the tables). This phenomenon is known as chóngniǔ 重粈. To reconstruct the situation at the first stage of the phonetic changes, it is necessary to remove this $-\mathrm{j}$ - mentally from the B rimes (Table 6.2: column 8).

\subsection{Mergers of rimes}

4.2.1 Table 7.1 (below) shows mergers of OC rimes ending in - $\mathrm{n}$ into MC (corrected for the chóngniǔ phenomenon) according to types A and B (without medial -r-). These mergers are, like the vocalic split, a widespread characteristic of languages with voice type registers.

- In type A, there are two rime mergers, (i) OC -in, -en and T-in on the one hand, and (ii) $\mathrm{OC}$-un and P-in on the other hand.

- In type $\mathrm{B}$, one observes three groups of mergers, different from the preceding ones: (i) OC -in and T-in, (ii) OC P-in and PK-un, and (iii) OC -en and T-an.

Table 7.1 : Mergers of OC (without medial -r-) into MC: rimes ending in -n

Type A

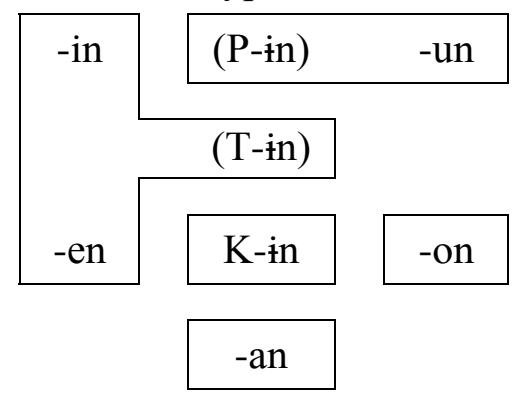

Type B

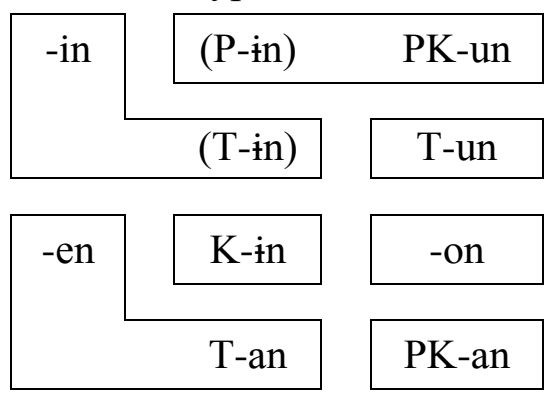

It is likely that the mergers of the rimes P-in into P-un on the one hand, and of the rimes $\mathrm{T}$-in into $\mathrm{T}$-in on the other, occurred before the vocalic split, around late OC. For the sake of clarity, the rimes P-in and T-in, although present no longer (in theory), are placed between parentheses in Table 7.1. These mergers appear to result from a process of reduction of the number of the vowels of OC by elimination of the rime -in except after initial $\mathrm{K}$ because this process was interrupted by the bursting of registrogenesis phonetic features. The limitations of the present study do not enable us to look further into these phenomena, which deserve fuller treatment.

4.2.2 Table 7.2 (below) shows mergers of $\mathrm{OC}$ rimes ending in vowel into $\mathrm{MC}$ (corrected for the chóngniǔ phenomenon) according to types A and $\mathrm{B}$. These mergers are, like the vocalic split, a widespread characteristic of languages with voice type registers.

- $\quad$ In type A, the rimes $\mathrm{OC}-\mathbf{i}$ and -e merged.

- In type B, on can observe an incomplet merging, the rime OC P-i merged with $-\mathbf{u}$, while TK-i remains unmerged. 
Table 7.2: Mergers of OC rimes ending in vowel (without medial -r-) into MC

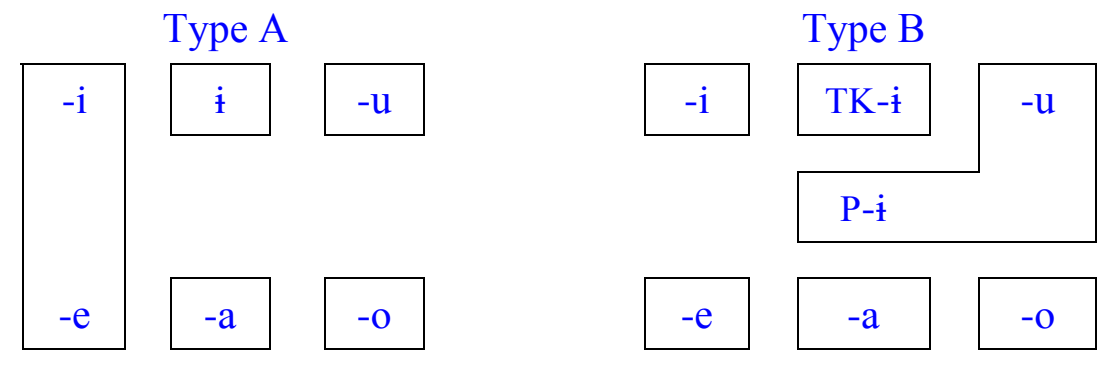

4.2.3 In MC, mergers of rimes are more sophisticated than in Mon-Khmer languages; they can depend on rows of initials, a conditioning which has not been observed elsewhere.

There is a perfect parallelism between the types A (tense) and B (lax) of MC, and the series known as 'high' (syllables reconstructed as having voiceless initials), and 'low' (syllables reconstructed as having voiced initials) of Mon-Khmer languages with voice type register (see Table 4 above).

\subsection{Presentation of the hypothetical rime system in two Divisions}

I reconstruct a hypothetical system in two Divisions which I will name Div. A (I/IV and II) and Div. B (III) by associating the symbols A and B with the numbers of future Divisions in the QY.

Table 8: Hypothetical rime system in two Divisions

\begin{tabular}{|c|}
\hline $\mathrm{A}(\mathrm{I} / \mathrm{IV}$ and $\mathrm{II})$ \\
\hline $\mathrm{B}(\mathrm{III})$ \\
\hline
\end{tabular}

Let us give some examples of pairs $\mathrm{A} / \mathrm{B}$ to illustrate the evolution of the six $\mathrm{OC}$ vowels towards $\mathrm{MC}$ vowels. These examples are for the most part drawn from Baxter's handbook. My own phonetic interpretations are placed between brackets. Presyllables are indicated by the symbol C.

Rimes with final $-\mathbf{n}$

A 丹 $d \bar{a} n<\mathrm{MC} \tan [\tan ]<\mathrm{OC} * \tan [$ C.tan] "cinnabar"

$\mathrm{B}$ 旃 $z h \bar{a} n<\mathrm{MC}$ tsyen [ţ̣ièn] < OC *tjan [tan] "kind of red banner"

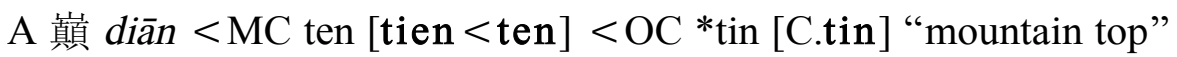

$\mathrm{B}$ 真 $z h \bar{e} n<\mathrm{MC}$ tsyin [tçìn] < OC *tjin [tin] "true, real"

A 編 biān $<\mathrm{MC}$ pen [pien < pen] < OC *pen [C.pen] "plait, weave"

$\mathrm{B}$ 褊 biăn <MC pjienX [p-j-ièn $\left.{ }^{2}\right]<\mathrm{OC}$ *pjen? [pen?] "narrow"

$\mathrm{A}$ 殄 $\left[\right.$ tiăn] $<\mathrm{MC} \operatorname{denX}\left[\operatorname{tien}^{2}<\operatorname{ten}^{2}\right]<\mathrm{OC} * \operatorname{din} ?$ [C.din?] “exterminate"

$\mathrm{B}$ 辰 chén < MC dzyin [dzìn] < OC *djin [din] "fifth Earthly Branch"

$\mathrm{A}$ 昆 $[k \bar{u} n]<\mathrm{MC}$ kwon [kwən] $<\mathrm{OC}$ *kun [C.kun] "elder brother"

$\mathrm{B}$ 君 jūn < MC kjun [kùn] < OC *kjun [kun] "lord”

A 冠 guān < MC kwan [kwan] < OC *kon [C.kon] “cap"

$\mathrm{B}$ 元 yuān < MC ngjwon [yuòn] < OC *Nkjon ["kon] "principal, head" 
Rimes with final vowel

A 睹 $d \check{u}<\mathrm{MC}$ tu $[\mathrm{tu}]<\mathrm{OC} *$ ta [C.ta] "capital, city"

$\mathrm{B}$ 諸 $z h \bar{u}<\mathrm{MC}$ tsyo (tsy-jo) [ţ⿳亠口冋] < OC *tja [ta] "many"

A 稽 $j \bar{i}<\mathrm{MC}$ kej [kej] <OC *kij [C.kij] "accord with"

$\mathrm{B}$ 脂 $z h \bar{i}<\mathrm{MC}$ tsyij (tsy-ij) [tcìj] < OC *kjij [kij] "fat, grease"

A 雞 $j \bar{i}<\mathrm{MC}$ kej $[\mathrm{kej}]<\mathrm{OC} * \mathrm{ke}[\mathrm{C} . \mathrm{ke}]$ "chicken"

$\mathrm{B}$ 枝 $z h \bar{i}<\mathrm{MC}$ tsye (tsy-je) [ţ⿳亠े] $<\mathrm{OC} * k e[\mathrm{ke}]$ "branch"

A 辰 chén <MC pwoj (p-woj) [pəj] < OC *pi [C.pi் “cup"

$\mathrm{B}$ 不 bù $<\mathrm{MC}$ pjuw [pùw] $<\mathrm{OC}$ *pji [pí] “not"

A 猱 náo $<\mathrm{MC}$ naw [naw] $<\mathrm{OC} *$ nu [C.nu] "a kind of monkey"

$\mathrm{B}$ 柔 róu < MC nyuw (ny-juw) [nùw] < OC *nju [nu] "soft"

A 洎 $d \bar{o} u<\mathrm{MC}$ tuw [tuw] < OC *to [C.to] "helmet, hood"

$\mathrm{B}$ 朱 $z h \bar{u}<\mathrm{MC}$ tsyu (tsy-ju) [tढù ] < OC *tjo [to] "dwarf"

\section{Evidence for a rime system in three Divisions}

\subsection{Rimes from OC (with medial -r-) to MC}

The phenomenon of lenition of medial $-r$ - is the second great change of the history of rimes $\mathrm{OC}>\mathrm{MC}$. It is thought that this phenomenon must have occurred around the 4th century CE (end of 3rd century to the first third of 5th century). This change developed gradually, starting with the velarization of $-r-$, to end in its complete lenition while leaving a modification on the vowel. The new rimes are generated from the rimes of the syllables with a $\mathrm{T}$ initial (recall that $\mathbf{r}$ is an acute consonant like $\mathrm{T}$ ).

Table 9.1 is composed only of rimes $\mathrm{MC}<\mathrm{OC}$ (with medial $-\mathbf{r}-$ ). It is a reinterpretation of columns 5-6 in Table 5.1. In each type, the rimes are given according to three transcriptions, as above.

Table 9.1: From OC (with medial -r-) to MC: rimes ending in $-\mathbf{n}$

\begin{tabular}{|c|c|c|c|c|c|c|c|}
\hline 1 & 2 & 3 & 4 & 5 & 6 & 7 & 8 \\
\hline $\mathrm{OC}$ & & \multicolumn{3}{|c|}{ MC (type A) } & \multicolumn{3}{|c|}{ MC (type B) } \\
\hline Baxt. & & Baxt. & Pull. & Ferlus & Baxt. & Pull. & Ferlus \\
\hline- ran & PTK & -æn & -ain & $-^{\mathrm{V}}$ an $(>-æ n)$ & -jen & -ian & -ièn \\
\hline -rin & PTK & $-\varepsilon n$ & - əin & $-{ }^{\gamma}$ en $(>-\varepsilon n)$ & -in & -in & -ìn \\
\hline -ren & PTK & $-\varepsilon n$ & - əin & $-{ }^{\gamma}$ en $(>-\varepsilon n)$ & -jen & -ian & -ièn \\
\hline -rin & PTK & $-\varepsilon n$ & $-\partial \dot{\text { in }}$ & $-{ }^{\mathrm{r} e n}(>-\varepsilon n)$ & -in & -in & -ìn \\
\hline -run & PTK & -wen & -wə⿱亠䒑 & $-{ }^{-}$WEn $(>-w \varepsilon n)$ & -win & -win & -uìn \\
\hline -ron & PTK & -wæn & -wain & $-{ }^{-}$wan $(>-w æ n)$ & -jwen & -wian & -uèn \\
\hline
\end{tabular}

The lenition of -r- had as a consequence a second vocalic split which enriched the system of rimes.

- In type A, there was a creation of a paradigm of new rimes. These rimes, marked here by means of $-^{{ }^{-}}$, make up the Division traditionally known as Div. II. Thereafter, velarization continued until lenition, yielding new vowels, probably rather close to the reconstructions proposed by Baxter (Table 9.1, column 5). 
- In type B, on the other hand, the new rimes are on the whole identical to the former rimes resulting from the first vocalic split. Contrary to expectations, there was no creation of a new paradigm of rimes (this anomaly will be explained in §7.2). However, to forestall confusion, the rimes resulting from $\mathrm{OC}$-in/-en after grave initials were lengthened by the insertion of $a-j-$ (a true medial). It is noteworthy that this lengthening did not occur in the rimes with $\mathrm{T}$ initials. That is probably due to the early retroflexion of apicals before medial -r-.

Table 9.2: From OC (with medial -r-) to MC: rimes ending in vowel

\begin{tabular}{|c|c|c|c|c|c|c|c|}
\hline 1 & 2 & 3 & 4 & 5 & 6 & 7 & 8 \\
\hline $\mathrm{OC}$ & & \multicolumn{3}{|c|}{ MC (type A) } & \multicolumn{3}{|c|}{ MC (type B) } \\
\hline Baxt. & & Baxt. & Pull. & Ferlus & Baxt. & Pull. & Ferlus \\
\hline$-\mathrm{ra}$ & $\mathrm{P}$ & -wæ & -waí/we: & $-{ }^{\mathrm{\gamma}} \varepsilon$ & $-j u$ & -uว̆ & -uว̀ \\
\hline$-r a$ & TK & $-æ$ & $-a \dot{i} / \varepsilon:$ & $-{ }^{\mathrm{Y}} \mathfrak{Z}$ & - jo & 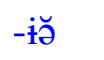 & -ì̀ \\
\hline$-r i / r i j$ & PTK & $-\varepsilon j$ & $-\partial \mathrm{ij} / \varepsilon \dot{\mathrm{j} j}$ & $-{ }^{\mathrm{V}} \mathrm{ej}$ & $-\mathrm{ij}$ & $-\mathrm{i}$ & -ì \\
\hline -re & PTK & $-\varepsilon \dot{\dot{q}}$ & $-a \mathrm{ijj} / \varepsilon \mathrm{ij}$ & $-{ }^{\mathrm{\gamma}} \varepsilon \partial$ & - je & -iă/iə & -iè \\
\hline$-r \dot{x}$ & PTK & $-\varepsilon j$ & $-\partial \mathrm{ijj} / \varepsilon: \mathrm{ij}$ & $-{ }^{\mathrm{V}} \dot{\varepsilon \dot{q}}$ & $-\mathrm{ij}$ & $-\mathrm{i} / \mathrm{i}$ & -ì \\
\hline$-r u$ & PTK & -æw & -aiw/E:w & $-{ }^{8} \dot{i} w$ & -juw & -uw & $-u ̀$ \\
\hline -ro & PTK & $-u w$ & $-\partial W$ & - - & $-j u(w)$ & $-u w$ & $-u ̀ ~$ \\
\hline
\end{tabular}

5.2 Mergers of rimes

Table 10.1: Mergers of OC rimes ending in -n (with medial -r-) into MC

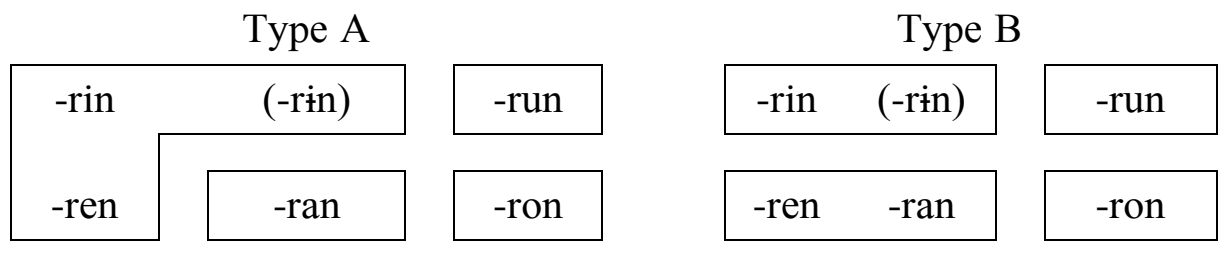

It has been shown above $(\S 4.2)$ how the rimes $\mathrm{T}$-in had to merge early into T-in. The medial -r- behaving like an acute initial, the rime -rin which was thus merged with -rin is placed between parenthesis.

Table 10.2: Mergers of OC rimes ending in vowel (with medial -r-) into MC

Type A

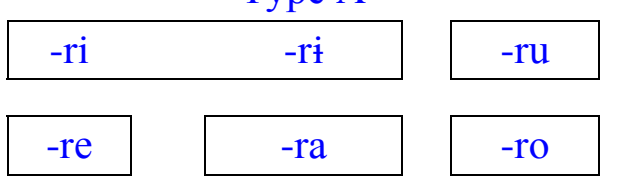

Type B

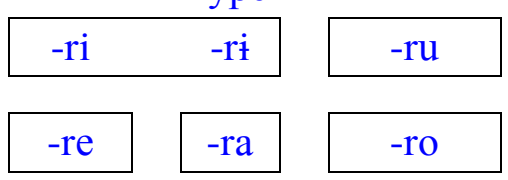

Rimes -ri and -ri merged in both type, A and B. 
5.3 Presentation of the hypothetical rime system in three Divisions

We have here a hypothetical system in three Divisions: A (future I/IV), A (future II) and B (future III).

Table 11: Hypothetical rime system in three Divisions

\begin{tabular}{|c|c|}
\hline $\mathrm{A}(\mathrm{I} / \mathrm{IV})$ & $\mathrm{A}(\mathrm{II})$ \\
\hline \multicolumn{2}{|c|}{$\mathrm{B}(\mathrm{III})$} \\
\hline
\end{tabular}

Here are examples of some triads contrasting A (I/IV) <OC (without medial -r-), $\mathrm{A}$ (II) $<\mathrm{OC}$ (with $-\mathrm{r}-$ ), and $\mathrm{B}$ (III) < OC (without $-\mathrm{r}-$ ). To simplify, only rimes ending in $-\mathrm{n}$ are given.

A (I) 干 gān <MC kan [kan] < OC *kan [C.kan] "shield"

A (II) 姦 jiān $<$ MC kæn [kæn $\left.<\mathrm{k}^{\mathrm{\gamma}} \mathrm{an}\right]<\mathrm{OC} * \mathrm{kran}[\mathrm{kran}]$ "adultery"

$\mathrm{B}$ (III) 鞬 jiān <MC kjon [kì̀n $]<\mathrm{OC} *$ kjan [kan] "bow and arrow case"

A (I) 冠 guān <MC kwan [kwan] < OC *kon [C.kon] “cap"

A (II) 關 guān $<\mathrm{MC}$ kwæn [kwæn $<\mathbf{k}^{\mathrm{\gamma}} \mathbf{w a n}$ ] $<\mathrm{OC}$ *kron [kron] "barrier"

$\mathrm{B}$ (III) 元 yuān <MC ngjwon [yuòn] < OC *Nkjon [ ["kon] "principal, head"

A (I) 昆 [kūn] <MC kwon [kwən] < OC *kun [C.kun] "elder brother"

$\mathrm{A}$ (II) 綸 guān $<\mathrm{MC}$ kwen [kwen $\left.<\mathrm{k}^{\mathrm{\gamma}} \mathrm{wen}\right]<\mathrm{OC} * \mathrm{krun}[\mathrm{krun}]$ "head kerchief"

$\mathrm{B}$ (III) 君 jūn < MC kjun [kùn] < OC *kjun [kun] "lord"

$\mathrm{A}$ (I) 根 $g \bar{e} n<\mathrm{MC}$ kon [kən] $<\mathrm{OC} *$ kin [C.kin] "root"

$\mathrm{A}$ (II) 艱 jiān $<\mathrm{MC}$ ken [ken $\left.<\mathrm{k}^{\mathrm{y} e n}\right]<\mathrm{OC} * \mathrm{krin}[\mathrm{krin}]$ "distress, difficulty"

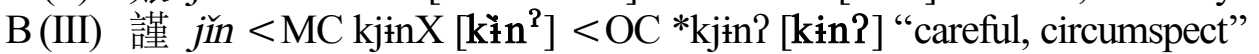

A (IV) 肩 jiān < ken [kien < ken] < OC *ken [C.ken] "shoulder"

A (II) 間 jiān $<\mathrm{k \varepsilon n}\left[\mathrm{k} \varepsilon \mathbf{n}<\mathrm{k}^{\mathrm{y}} \mathrm{en}\right]<\mathrm{OC} * \mathrm{kren}[\mathrm{kren}]$ "between"

$\mathrm{B}$ (III) no convincing example

\section{Traditional rime system in four Divisions}

In $\S 4$ and $\S 5$, we have reconstructed hypothetical systems in two and in three Divisions, supposed to have preceded the 'canonical' traditional system in four Divisions described in the QY. The formation of these supposed first systems is based on phonetic changes that are clearly identified: (i) the two-way split of the OC vowel system, and (ii) the lenition of medial -r-.

In the QY, Divs. I and IV are in complementary distribution, which reduces the system to three functional Divisions. Div. IV comprises only one vowel, written e by Baxter and $\varepsilon$ by Pulleyblank. Karlgren, on the other hand, reconstructed a front diphthong which he noted differently -ie-/-ia-/-io- depending on the group of rimes. Li Fang-kuei (1974-75) also interpreted Div. IV by a diphthong. I propose, like these authors, to reconstruct ie, more precisely e $>$ ie to show that the diphthong is a late development.

Table 12: Rime system in four Divisions (three functional Divisions)

\begin{tabular}{|c|c|}
\hline $\mathrm{A}(\mathrm{I}) / \mathrm{A}(\mathrm{IV})$ & $\mathrm{A}(\mathrm{II})$ \\
\hline \multicolumn{2}{|c|}{$\mathrm{B}(\mathrm{III})$} \\
\hline
\end{tabular}


The front diphthong ie will be the mark of Div. IV. However, it is difficult to tell whether the change $\mathbf{e}>$ ie preceded or followed velarization.

\section{The lost Division and its traces}

It has been seen, in what precedes, that in the process of the lenition of medial -r-, only the rimes of type A formed a new paradigm (Tables 9.1, 9.2 and Tables 10.1, 10.2). These new rimes constitute Div. A (II). On the other hand, in type B there was no such formation of new rimes. A Division appears to have been lost in the course of changes. At first sight, this constitutes an anomaly. However, phenomena of mergers of certain rimes B (III) towards A (IV) or A (II) can be explained only by reference to this hypothesized lost Division. These transfers of rimes are of two kinds: B (III) towards A (IV), giving rise to the chóngniǔ pairs, and B (III) towards A (II) at the time of the TSrj->TSr- change.

\subsection{The loss of medial -r- did not create new rimes in type B}

Rimes of the type A created by the lenition of -r- formed Division A (II). They derive from the former rimes after acute initials that were formed by vocalic splitting. Against all expectations, there was no formation of new rimes in type B. A system with five Divisions (or four functional Divisions) would be expected, and yet no formation of a Division corresponding to Div. A (II) took place, to parallel the relationship of Div. B (III) to A (I/IV). One Division was lost! If one notes this lost Division as $\mathrm{B}(\mathrm{X})$, the expected system can be imagined as follows:

Table 13: *Expected rime system in five Divisions

\begin{tabular}{|c|c|}
\hline $\mathrm{A}(\mathrm{I}) / \mathrm{A}(\mathrm{IV})$ & $\mathrm{A}(\mathrm{II})$ \\
\hline $\mathrm{B}(\mathrm{III})$ & $\mathrm{B}(x)$ \\
\hline
\end{tabular}

What can be the reasons for this anomaly?

Let us point out once again the striking parallelism observed between types $A / B$ in Chinese, on the one hand, and on the other hand the high/low series in voice type register languages of the Mon-Khmer family. In these languages, the vowels of the low series are characterized by a bundle of phonetic features: laxness of speech organs, pitch lowering, tendency for raising of the vowel onset, and breathiness. By analogy, it was suggested above (see $\$ 2.1$ and Table 2) that this breathiness must have existed on the rimes of the type B whose reconstructions testified to phenomena of laxness and of vocalic raising. It has been decided that this breathiness, indicated by $[\grave{v}$, was the mark of the hypothetical system in two Divisions.

Before the lenition of $-r$ - (i.e. softening), the change C-r-V(C)>C-r-V(C) initially produced a new segment $\left[-^{\gamma_{-}}\right]$, a kind of spirant, whose phonation was 'soft' and whose point of articulation was vague (by comparison with the precision of the point of articulation of stops). This new element came into contact with the breathiness carried by the vowel. It was phonetically impossible to realize distinctly

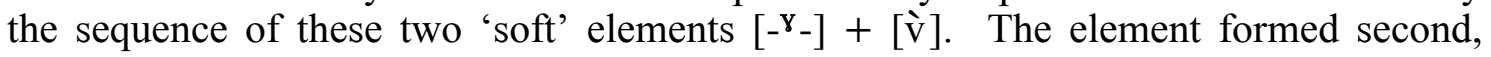
velarization, was absorbed by the element formed first, the breathiness. This is why there was no formation of a Division of type B corresponding to A (II), as B (III) corresponded to A (I/IV). 
One could be satisfied to conclude that Div. B (III) corresponds both to Divs. A(I/IV) and A(II). However, an attentive analysis leads us to consider two subdivisions in B(III), Div. B(III) itself and Div. B(III-4) which groups the lengthened rimes. Tables 14.1 and 14.2 aims to bring out these two subdivisions.

\subsection{Formation of chóngniǔ pairs}

The $\mathrm{B}$ rimes of the new paradigm (Table 14.1 and 14.2: columns 6-7-8) formed by the lenition of -r-, are the same ones as the B rimes of the former paradigm (columns 3-4-5) formed after acute initials. The organization of the rimes which results from these changes created a risk of confusion in $\mathrm{MC}$ rimes originating in $\mathrm{OC}$ rimes with vowels $\mathbf{i}$ and e. The other vowels were not affected.

Table 14.1: MC rimes of type B: rimes ending in $-\mathbf{n}$

\begin{tabular}{|c|c|c|c|c|c|c|c|c|c|}
\hline 1 & 2 & 3 & \multicolumn{3}{|c|}{5} & 6 & 7 & \multicolumn{2}{|l|}{8} \\
\hline \multirow{2}{*}{\multicolumn{2}{|c|}{$\begin{array}{c}\text { OC } \\
\text { Baxt. }\end{array}$}} & \multicolumn{4}{|c|}{$\mathrm{MC}<\mathrm{OC}$ (without -r-) } & \multicolumn{4}{|c|}{$\mathrm{MC}<\mathrm{OC}$ (with -r-) } \\
\hline & & Baxt. & Pull. & Ferlus & & Baxt. & Pull. & Ferlu & \\
\hline \multirow{3}{*}{$-(r)$ an } & $\mathrm{P}$ & -jon & $-\operatorname{ian}$ & -ì̀n & III & -jen & -ian & -ièn & III \\
\hline & $\mathrm{T}$ & -jen & -ian & -ièn & III & -jen & -ian & -ièn & III \\
\hline & $\mathrm{K}$ & -jon & $-\tan$ & -ì̀n & III & -jen & -ian & -ièn & III \\
\hline \multirow{3}{*}{$-(\mathrm{r})$ in } & $\mathrm{P}$ & - jin & $-\mathrm{jin}$ & -j-ìn (<ìn) & III-4 & -in & -in & -ìn & III \\
\hline & $\mathrm{T}$ & -in & -in & -ìn & III & -in & -in & -ìn & III \\
\hline & $\mathrm{K}$ & - jin & - jin & -j-ìn (<ìn) & III-4 & -in & -in & -ìn & III \\
\hline \multirow{3}{*}{$-(r)$ en } & $\mathrm{P}$ & -jien & -jien & -j-ièn (<ièn) & III-4 & -jen & -ian & -ièn & III \\
\hline & $\mathrm{T}$ & -jen & -ian & -ièn & III & -jen & -ian & -ièn & III \\
\hline & $\mathrm{K}$ & -jien & -jien & -j-ièn (<ièn) & III-4 & -jen & -ian & -ièn & III \\
\hline \multirow{3}{*}{$-(r)$ in } & $\mathrm{P}$ & -jun & -un & -ùn & III & -in & -in & -ìn & III \\
\hline & $\mathrm{T}$ & -in & -in & -ìn & III & -in & -in & -ìn & III \\
\hline & $\mathrm{K}$ & -jin & -in & -in & III & -in & -in & -ìn & III \\
\hline \multirow{3}{*}{-(r) un } & $\mathrm{P}$ & -jun & -un & -ùn & III & -win & -win & -uìn & III \\
\hline & $\mathrm{T}$ & -win & -win & -uìn & III & -win & -win & -uìn & III \\
\hline & $\mathrm{K}$ & -jun & -un & -ùn & III & -win & -win & -uìn & III \\
\hline \multirow{3}{*}{$-(r)$ on } & $\mathrm{P}$ & -jwon & -uan & -uòn & III & -jwen & -wian & -uèn & III \\
\hline & $\mathrm{T}$ & -jwen & -wian & -uèn & III & -jwen & -wian & -uèn & III \\
\hline & $\mathrm{K}$ & -jwon & -uan & -uòn & III & -jwen & -wian & -uèn & III \\
\hline
\end{tabular}

This potential confusion was avoided by the insertion of a yod $-\mathbf{j}$ - which lengthened the vowel (see §4.1.1). This phenomenon concerns only the rimes with MC vowels $\grave{i}$ and iè (Baxter $i$ and $j e$ ) after the grave initials $(\mathrm{P} \mathrm{K})$. The rimes after acute initials (T) are not affected by this lengthening. The writers of rime tables transferred these 
lengthened rimes from Div. III into Div. IV. This is why they are symbolized here by $\mathrm{B}$ (III-4). The pairs of contrastive rimes -ìn $\sim-$ jìn and -ièn $\sim$-jièn (Baxter - in $\sim-j$ in and $-j e n \sim-j i e n)$ form the chóngniǔ pairs. These transferred rimes provide evidence for the lost Division.

Table 14.2: $\mathrm{MC}$ rimes of type B: examples of rimes ending in vowel

\begin{tabular}{|c|c|c|c|c|c|c|c|c|c|}
\hline 1 & 2 & 3 & 4 & \multicolumn{2}{|l|}{5} & 6 & 7 & \multicolumn{2}{|l|}{8} \\
\hline $\mathrm{OC}$ & & \multicolumn{4}{|c|}{$\mathrm{MC}<\mathrm{OC}$ (without $-\mathrm{r}-$ ) } & \multicolumn{4}{|c|}{$\mathrm{MC}<\mathrm{OC}$ (with -r-) } \\
\hline Baxt. & & Baxt. & Pull. & Ferlus & & Baxt. & Pull. & Fer & \\
\hline \multirow{3}{*}{$-(r) i$} & $\mathrm{P}$ & $-\mathrm{jij}$ & $-\mathrm{ji}$ & $-\mathrm{j}-\mathrm{ijj}(<\mathrm{ijj})$ & III-4 & $-\mathrm{ij}$ & $-\mathrm{i}$ & $-1 \mathrm{j}$ & III \\
\hline & $\mathrm{T}$ & $-\mathrm{ij}$ & $-\mathrm{i}$ & $-i ̀ j$ & III & $-\mathrm{ij}$ & $-\mathrm{i}$ & $-i ̀ j$ & III \\
\hline & $\mathrm{K}$ & $-\mathrm{jij}$ & $-\mathrm{ji}$ & $-j-i ̀ j(<i ̀ j)$ & III-4 & $-\mathrm{ij}$ & $-\mathrm{i}$ & $-i ̀ j$ & III \\
\hline \multirow{3}{*}{$-(r) e$} & $\mathrm{P}$ & -jie & $-\mathrm{jiă} / \mathrm{ji}$ & -j-iè (<iè) & III-4 & $-\mathrm{je}$ & $-\mathrm{iă} / \mathrm{i} \partial$ & $-\mathrm{iè}$ & III \\
\hline & $\mathrm{T}$ & $-\mathrm{je}$ & $-\mathrm{i} \breve{\partial} / \mathrm{i}$ & -iè & III & $-\mathrm{je}$ & -iă / iə & $-\mathrm{iè}$ & III \\
\hline & K & -jie & $-\mathrm{jiă} / \mathrm{ji}$ & -j-iè (<iè) & III-4 & $-\mathrm{je}$ & $-i a ̆$ / iə & $-\mathrm{iè}$ & III \\
\hline
\end{tabular}

Baxter (1992: 75-77) very clearly explained the chóngniǔ pairs and their place among the rimes of MC. He refocused attention on this phenomenon which had somehow come to be neglected in other publications.

Some examples of chóngniǔ pairs (Baxter 1992: 75-77)

B (III) 貧 pín < bin III [bìn] < *brjin [brin] “poor”

B (III-4) 蘋 pín < bjin IV [b-j-ìn] < *bjin [bin] "frequently"

B (III) 乙 yǐ < ?it III [?ìt] <*2rjit [?rit] "2nd heavenly branch"

B (III-4) 一 yi < Pjit IV [?-j-ìt] <*?jit [?it] "one"

B(III) 天 yāo < Pjew III [? èw] <*?(r)jaw [?raw] "beautiful"

B (III-4) 腰 yāo < ?jiew IV [?-j-èw] <*?jew [?ew] "waist"

B (III) 陂 pí bēi <pje III [pè]<* * p(r)jaj [praj] "slope, dyke"

B (III-4) 卑 $b \bar{e} i<$ pjie IV [p-j-è] <*pje [pe] "low, humble"

The formation of these pairs is a consequence of the lenition of the medial -r-. To summarize, in type $\mathrm{B}$, there was no formation of a new paradigm of rimes corresponding to A(II), as B (III) corresponded to A(I/IV). To avoid confusion, certain rimes of the former paradigm were lengthened by the insertion of $-\mathbf{j}-$. These lengthened rimes fell into contrast with homologous rimes of the new paradigm (formation of chóngniǔ pairs) and were transferred from Div. III into Div. IV, forming a non-canonical virtual Division which I call B(III-4).

The process of the formation of the chóngniǔ pairs is now clear, but it remains to be understood why these rimes were transferred from Div. III to Div. IV. The lengthening by $-\mathbf{j}$ - of rimes III-4 led to the formation of units $\mathbf{j i ̀ ~ a n d ~} j \mathrm{jè} \mathrm{that} \mathrm{are} \mathrm{similar}$ to diphthongs. As Div. IV is characterized by the diphthong ie $(<\mathbf{e})$, it seems quite reasonable to think that the transfer took place on the basis of phonetic similarity between $\mathbf{j i ̀} / \mathbf{j i e ̀ ~ a n d ~ i e , ~ r e i n f o r c e d ~ b y ~ t h e ~ l o s s ~ o f ~ t h e ~ b r e a t h i n e s s . ~}$

Evidence of rime contrast within chóngniǔ pairs lasted until the 13th century. After this date, the rimes merged. 


\subsection{Evidence of chóngniǔ in Sino-Vietnamese}

Sino-Vietnamese (hereafter SV), a Sino-xenic dialect formed around the 11th-12th centuries, attests an original treatment of the rimes B (III-4) after the labial initials (P) and the laryngeal initial ? (Pulleyblank 1984: 94; Ferlus 1992: 115).

- The labial initials correspond to $\mathbf{t}$ or $\mathbf{t}^{\mathbf{h}}$ in Sino-Vietnamese ( $t$ or th in romanization): 卑 $b \bar{e} i, \mathrm{MC}$ pjie, SV ty "low, humble"; 賓 bìn, MC pjin, SV tân “guest”; 匹 p̌r, MC phjit, SV thất "few in number"; 偏 piān, MC phjien, SV thiên "slanting". These correspondences, a priori surprising, are the result of a chain of regular changes observed in the historical phonetics of Vietnamese (Ferlus 1992), namely:

賓 bīn, MC pjin, analized as a disyllabic [p.jìn]> (Northern Vietnamese) p.zin $>$ (monosyllabization) zin $>$ (devoicing) $\sin >$ sən $>$ (occlusivization of s) tən, SV tân "guest".

偏 piān, MC phjien, analyzed as a disyllabic [p. ${ }^{\mathrm{h}}$ jièn] $>$ (Northern Vietnamese) p.zien $>$ (monosyllabization) zien $>$ (devoicing) cien $>$ (occlusivization of $\mathbf{6}$ ) $\mathrm{t}^{\mathrm{h}}$ ien, SV thiên "slanting".

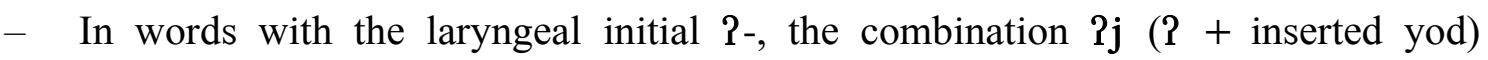
corresponds to the nasal palatal $\mathrm{n}$ in Sino-Vietnamese ( $\mathrm{nh}$ in romanization): - $y \overline{\mathbf{i}}$, MC 2jit, SV nhất "first"; 因 yinn, MC 2jin, SV nhân "depend on". Old Vietnamese has a series of three preglottalized plosives, $\mathbf{b}, \boldsymbol{d}, \boldsymbol{f}$, represented today by the nasals $\mathbf{m}, \mathbf{n}, \mathbf{n}(m, n, n h$ in romanization). In Sino-Vietnamese, the initial combination $\mathbf{i j}$ - was interpreted as the former preglottalized palatal $f$ and is thus represented by present-day $n h$ :

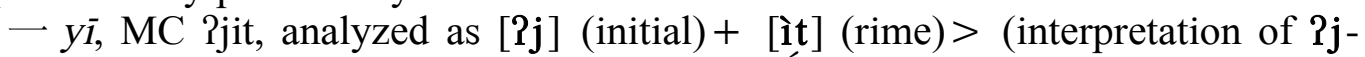
by $f$-) fit $>$ (nasalization of $f$ ) jit $>$ nət, SV nhất "first".

因 yinn, MC ?jin, analyzed as [?j] +[ìn]> (interpretation of $2 j-$ by $f-$ ) fin $>$ (nasalization of $f$ ) jin $>$ nən, SV nhân "depend on".

It is necessary to insist on the fact that these changes are quite regular from the point of view of the rules of the phonetic history of Vietnamese.

\subsection{The change TSrj- $>$ TSr- according to Baxter}

After sibilant initials TS $\left(\mathbf{t s}, \mathbf{t} \mathbf{s}^{\mathbf{h}}, \mathbf{d z}, \mathbf{s}\right)$, certain rimes normally expected in Div. III were transferred to Div. II. This phenomenon, that Baxter formalizes as TSrj->TSr-, is set out at several places in his work (1992: $§ 2.3 .6, \S 7.2 .3, \S 10.1 .1 .1 / 2$ and appendix A.31). Let us compare the three following examples in parallel:

(1) 顏 yán < ngæn [yæn < $<\mathfrak{y}^{\vee}$ an] II <*ngran [C.yran] "face, countenance"

(2) 山 shān $<\operatorname{sr\varepsilon n}\left[\mathbf{s} \varepsilon \mathbf{n}<\mathbf{s}^{\mathrm{y}} \varepsilon \mathbf{\varepsilon}\right]$ III-2 <*srjan [sran] "mountain"

(3) 廛 chán < drjen [dièn] III <*drjan [dran] "farmyard"

The place of (1) is regular in Div. II. In the same way, the place of (3) is regular in Div. III. But with regard to example (2) with a sibilant as initial, the fănqiè spelling shows that this rime undergoes an unexpected evolution between the stage of Qièyùn and that of Guăngyùn while passing from Div. III into Div. II. This phenomenon, though well observed, has not received an explanation so far.

Let us notice first of all that this apparent anomaly occurs in the context of the conflict between the two 'soft' articulations, the velarization [- $\left.{ }^{-}{ }_{-}\right]$issuing from medial $-r-$, and breathiness [ì]. Normally, in this situation, breathiness should eliminate velarization (see §7.1). Generally, 'soft' contexts are favorable to the emergence of 
irregularities. My own interpretation is that the 'sibilant' feature of initials TS reinforced the velarization which consequently won out over breathiness, moving these rimes from the expected Div. III towards Div. II. These rimes form a kind of noncanonical virtual Division which can be symbolized by B (III-2).

Example (4) below, detailed by Baxter (1992: §10.1.1.1), comes in support of example (2) while showing that the inversion of the change occurs between the stage of Qièyùn (QY) and that of Guăngyùn (GY).

(4) 產 [chăn] < GY sren ${ }^{\mathrm{X}}$ III-2 <QY $\operatorname{srjen}^{\mathrm{X}}$ III <*sngrjan? "breed, bear"

The change TSrj-> TSr- can be considered as another trace of the lost Division.

\subsection{Underlying rime system in four Divisions}

The transfers of rimes examined above, rimes B(III-4) of the chóngniǔ pairs, and B (III-2) originating in the change TSrj->TSr-, could occur only because, following the lenition of -r-, there was a tendency to form a new Division grouping type B rimes, to which I refer, for mnemonic convenience, as the lost Division.

It is thus possible to present the linguistic system that underpins the traditional system in four Divisions.

Table 15: Underlying rime system in four Divisions

\begin{tabular}{|c|c|}
\hline A (I) / A (IV) & A (II) \\
\hline B (III-4) & B (III-2) \\
\hdashline $\mid 2$ \\
\hline \multicolumn{2}{|c|}{ B (III) } \\
\hline
\end{tabular}

This analysis, which results very straightforwardly from the adoption of a functional perspective, brings to light the underlying structure of the four Divisions.

\section{The four Divisions: Meaning, conception and history}

The phonetic bases of the traditional system of the QY with four Divisions are now well identified. In this paper, I have set out the sequence of sound changes that took place from OC to MC. I have established the existence of 'predynastic' hypothetical former stages: a system in two Divisions, then a system in three Divisions. I have detected the loss of a Division and its survival through lengthened rimes. These clarifications were possible thanks to the models of sound change resulting from research on various languages of Southeast Asia, particularly Mon-Khmer languages.

\subsection{Phonetic contents of the four traditional Divisions}

The Divisions do not reflect a single type of contrast. Three types of phonetic features can be detected.

- Breathiness, a suprasegmental 'soft' feature, characterizes the vowels of B (III) in contrast to the vowels of A (I/IV) and A (II).

- Velarization, a segmental 'soft' feature (resulting from -r-), characterizes A (II) in contrast to A (I/IV) and B (III).

- The diphthong ie $(<\mathbf{e})$ characterizes A(IV) which is in complementary distribution with A(I). 
The preceding analyses enable us to propose a phonetic interpretation of each of the four Divisions of the QY, to which we add the traces of the lost Division.

$\begin{array}{llll}\text { I } & \mathrm{CV}(\mathrm{C}) & \text { non ie vowels } & \mathrm{A} \\ \text { IV } & \mathrm{Cie}(\mathrm{C}) & \text { ie vowel } & \mathrm{A} \\ \text { II } & \mathrm{C}^{\mathrm{r} V(C)} & \text { velarization } & \mathrm{A} \\ \text { III } & \mathrm{CV}(\mathrm{C}) & \text { breathiness } & \mathrm{B}\end{array}$

Traces of the lost Division

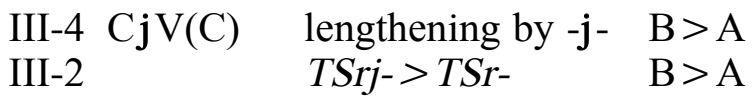

Let us attempt to schematize an overall system:

Table 16: The four traditional Divisions and the traces of the lost Division

\begin{tabular}{|c|c|c|c|}
\hline $\begin{array}{c}\text { A } \\
\text { (tense) }\end{array}$ & $\begin{array}{c}\text { I } \\
\text { (non -ie-) }\end{array}$ & $\begin{array}{c}\text { IV } \\
(- \text { ie- })\end{array}$ & $\begin{array}{c}\text { II } \\
\text { (velarized vowels) }\end{array}$ \\
\hline B & III-4 (lengthened) & III-2 (TSrj->TSr-) \\
(lax) & \multicolumn{3}{|c}{ III (breathy vowels) } \\
\hline
\end{tabular}

A close look at the linguistic diversity within the Mon-Khmer language family of Southeast Asia shows that the unstable features associated with the registral series eventually disappear and are replaced by stable compensatory features. There are good reasons to think that Chinese went through this evolution. Tenseness and laxness are stabilized into modal voice while breathiness disappears. The vocalic onset modifications, lowering in $\mathrm{A}$ and raising in $\mathrm{B}$, are stabilized as diphthongs or plain vowels. Velarization disappears but leaves modifications on the vowel.

This analysis raises the issue of when the hypothesized system (which I believe the four Divisions system aimed to describe) came to move away from the state shown in Table 16. I think, without being able to prove it conclusively, that this stabilization of the language was accomplished by the 7 th century $\mathrm{CE}$. The fact that certain rimes of Div. B (III), with breathiness, were transferred towards Div. A(IV), without breathiness, in the formation of the chóngniǔ pairs suggests that the breathiness was not active any more. If this view is right, the QY seems to be an updated version of earlier descriptions that have not reached us. It is certain that the traditional system of four Divisions must have been elaborated at a stage when the breathiness and velarization were still active and contrastive.

Thereafter, after the stabilization of the language, the system of four Divisions was no more than a framework grouping the rimes without obvious reason, other than the fact of coming from a more ancient structure. One can easily understand the difficulties sinologists have encountered for a century: they have been trying in vain to understand and to reconstruct the phonetic meaning of the four Divisions system, basing themselves, for want of anything better, on late revisions of the QY.

\subsection{A tentative history of rime systems}

Based on the relative chronology of the sound changes, one could present four successive systems of Divisions: (i) a hypothetical system in two Divisions, (ii) a hypothetical system in three Divisions, (iii) the traditional system in four Divisions, supposed to be reflected in the QY, and (iv) an underlying system in four Divisions. 
The first system, although it corresponded to a phonetic reality, was apparently never the object of any description. If it had been, one can think that the Chinese analysts would have proposed a simple two-term classification, corresponding to rimes A and B, unlike what appears in the QY. After the velarization of the medial -r-, the new rimes that were created could have been classified in a Division *III. However, in the QY, Divisions are numbered in a different order, the hypothetical Division *II (rimes of type B) as number III, and *III as number II. One can thus conclude that this hypothetical system in two Divisions was never described.

The layout of Divisions in the QY is perfectly logical from a phonetic point of view. Divs. I and II group tense rimes (type A), Div. I for the least marked and Div. II for velarized ones. Div. III groups the lax rimes associated with breathiness (type B), and is in contrast with the two preceding ones. On the other hand, setting up a fourth category, Division IV, disrupts the harmony of the system in three Divisions. Its numbering does not indicate its true place in the system, where it is complementary to Div. I. One would expect a numbering which reflects this complementarity. It is clear that the Chinese analysts initially described a system with three Divisions. Following the change $\mathbf{e}>\mathbf{i e}$, they placed this new diphthong, which did not belong to any of the three earlier categories, in a new Division, which was numbered IV only because this number follows number III. Thereafter, lengthened rimes (B III-4) of the chóngniǔ pairs were transferred from Div. III into Div. IV. This is the stage of the Qiè Yùn.

One can imagine that Chinese analysts initially described a system in three Divisions. Thereafter, two successive modifications were added, the creation of Div. IV, then the transfer of the lengthened rimes into this new division. This remains mere speculation: a document proving the existence of a description of a system in three Divisions has not been found (as yet).

Dating the stages of developments of the QY is an interesting topic for future research.

\subsection{The Chinese authors of rimes systems were true linguists}

It is obvious that a modern description would have presented the Chinese facts in another manner. The writers of the QY used arrangements and linguistic concepts drawn from the Indian treatises worked out for the description of the Sanskrit language (Branner 2006b: 7-10). That worked well for the description of consonants and vowels. But to describe the phonetic features peculiar to the Chinese language of their time which did not exist in Sanskrit, and hence which were not described in the Indian treatises, the writers had to conceive new categories of linguistic description: tones (shēng 聲) and Divisions (děng 等). The concept of tone, although appreciably different from its modern definition, is easily understood by modern scholars. On the other hand, the concept of Division has remained mysterious for a long time, as shown by the numerous unfruitful attempts at explanation. But the use of a single term, Division, made later readers believe, in their defense, that the divisions reflected a single type of phonetic contrast. In reality, Division reflects all that is not consonant, vowel or tone. The present reconstruction shows that Divisions were created to capture tenseness/laxness, vocalic breathiness and velarization. Later, a new division was created to account for the front diphthong.

The system of Divisions appears now as an ingenious framework reflecting several types of phonetic features. It was invented for the needs of the description of Chinese. The Chinese analysts were linguists avant la lettre. They were the first to describe a voice type register language. In light of the present research, it appears that 
their description is exact and precise. They set out in detail the result of their analyses: this is encapsulated in the Qièyùn. However, they did not provide an accompanying 'handbook' explaining their method and their descriptive tools. Moreover, as the Chinese language changed, the Divisions were emptied of their phonetic meanings and became an apparently arbitrary framework for regrouping rimes. That explains why modern scholars, Western as well as Chinese, struggled to discover the original meaning of the Divisions.

\section{References}

Baxter, William H. 1992. A Handbook of Old Chinese Phonology. [= Trends in Linguistics, Studies and Monographs 64]. Berlin: Mouton de Gruyter.

Baxter, William H. 1995. Les consonnes sonores finales du chinois archaïque. Lecture at Ecole des Hautes Etudes en Sciences Sociales. Paris. June 22, 1995.

Baxter, William H. \& Laurent Sagart. 2014. Old Chinese: a new reconstruction. Oxford University Press.

Branner, David P. ed. 2006a. The Chinese Rime Tables, Linguistic Philosophy and Historical-Comparative Phonology. Amsterdam: John Benjamins.

Branner, David P. 2006b. "Introduction: What are rime tables and what do they mean?" The Chinese Rime Tables ed. by David P. Branner, 1-34. Amsterdam: John Benjamins.

Casacchia, Giorgio. 1989. "Les débuts de la tradition linguistique chinoise et l'âge d'or de la linguistique impériale". Histoire des idées linguistiques, tome 1, Sylvain Auroux directeur: 431-448.

Coblin, W. South. 1996. "Northwest reflections on the Yunjing". T'oung Pao 82.349-363.

Cœdès, George. 1948. Les États hindouisés d'Indochine et d'Indonésie. Paris: de Boccard. [reprint 1989 with a new pagination]

Ferlus Michel. 1979. "Formation des registres et mutations consonantiques dans les langues môn-khmer". Mon-Khmer Studies 8.1-76.

Ferlus, Michel. 1992. "Histoire abrégée de l'évolution des consonnes initiales du Vietnamien et du Sino-Vietnamien". Mon-Khmer Studies 20.111-125.

Ferlus, Michel. 1998. "Du chinois archaïque au chinois ancien : Monosyllabisation et formation des syllabes tendu/lâche (Nouvelle théorie sur la phonétique historique du chinois)". The 31st International Conference on Sino-Tibetan Languages and Linguistics, University of Lund, Sweden.

Ferlus, Michel. 2005. "L'intérêt linguistique des transcriptions chinoises concernant le Cambodge ancien (Fou-nan et Tchen-la)". Dix-neuvièmes journées de linguistique de l'Asie Orientale, CRLAO (EHESS-CNRS), Paris.

Ferlus, Michel. 2012. "Remarques sur la pharyngalisation en chinois archaïque (Old Chinese) dans le système Baxter-Sagart". Vingt-cinquièmes Journées de Linguistique de l'Asie Orientale, CRLAO (CNRS-EHESS), 28-30 juin.

Gregerson, Kenneth J. 1976. "Tongue-root and register in Mon-Khmer". Austroasiatic Studies, part I ed. by Philip N. Jenner, Laurence C. Thompson Stanley Starosta, 323-369. Honolulu: University Press of Hawai'i. 
Handel, Zev Joseph. 1998. The Medial Systems of Old Chinese and Proto-SinoTibetan. MA University of California, Berkeley.

Haudricourt, André Georges. 1954a. "De l'origine des tons en vietnamien”. Journal Asiatique 242.69-82.

Haudricourt, André-Georges. 1954b. "Comment reconstruire le chinois archaïque". Word 10:2-3.351-364.

Haudricourt, André-Georges. 1961. "Bipartition et tripartition des systèmes de tons dans quelques langues d'Extrême-Orient". Bulletin de la Société de Linguistique de Paris 56:1.163-180. Translated and developed by Christopher Court: "Two-way and three-way splitting of tonal systems in some Far-Eastern languages". Tai Phonetics and Phonology ed. by Jimmy G. Harris \& Richard B. Noss, 1972: 5886. Bangkok: Mahidol University.

Henderson, Eugénie J.A. 1952. "The main features of Cambodian pronunciation". Bulletin of the School of Oriental and African Studies 14:1.149-174.

Hombert, Jean-Marie, John J. Ohala \& William G. Ewan. 1979. "Phonetic explanations for the development of tones". Language 55:1.37-58.

Huffman, Franklin E. 1976. "The register problems in fifteen Mon-Khmer languages". Austroasiatic Studies, part I ed. by Philip N. Jenner, Laurence C. Thompson \& Stanley Starosta, 575-589. Honolulu: University Press of Hawai'i.

Jacques, Guillaume. 2006. Introduction à la phonologie historique du chinois. Leiden.

Jenner, Philip N. 1974. "The development of the registers in Standard Khmer". Southeast Asian Linguistic Studies ed. by Nguyen Dang Liem, 47-60 [= Pacific Linguistics, Series C, No. 31, The Australian National University].

Karlgren, Bernhard. 1957. Grammata Serica Recensa. Stockholm: Museum of Far Eastern Antiquities [Reprint of Bulletin of the Museum of Far Eastern Antiquities 29.1-332].

Li Fang-kuei [Ľ̌ Fāngguì 李方桂]. 1974-75. “Studies on Archaic Chinese”. Monumenta Serica 31: 219-87. [Translation, by G.L. Mattos, of Li 1971]

Maspero, Henri. 1912. "Etudes sur la phonétique historique de la langue annamite: Les initiales". Bulletin de l'Ecole Française d'Extrême-Orient 12:1.1-127.

Matisoff, James A. 1973. "Tonogenesis in Southeast Asia". Consonant Types and Tone ed. by Larry M. Hyman, 75-92. Los Angeles: Southern California Occasional Papers in Linguistics.

Mazaudon, Martine. 1977. "Tibeto-Burman tonogenetics". Linguistics of the TibetoBurman Area 3:2.1-123.

Norman, Jerry. 1988. Chinese. New York: Cambridge University Press.

Norman, Jerry. 1994. "Pharyngealization in Early Chinese". Journal of the American Oriental Society 114:3.397-408. [Presented at the 25th International Conference on Sino-Tibetan Languages and Linguistics, 1992].

Pelliot, Paul. 1903. "Le Fou-nan”. Bulletin de l'École Française d'Extrême-Orient 3:2.248-303.

Pulleyblank, Edwin G. 1962. “The consonantal system of Old Chinese”. Asia Major 9:1.58-144 and 9:2.206-265.

Pulleyblank, Edwin G. 1970-1971. "Late Middle Chinese". Asia Major 15:2.197-233 and 16:1-2.121-168. 
Pulleyblank, Edwin G. 1984. Middle Chinese: A study in historical phonology. Vancouver: University of British Columbia Press.

Pulleyblank, Edwin G. 1991. Lexicon of Reconstructed Pronunciation in Early Middle Chinese, Late Middle Chinese and Early Mandarin. Vancouver: University of British Columbia Press.

Pulleyblank, Edwin G. 1994. "The Old Chinese origin of Type A and B syllables". Journal of Chinese Linguistics 22:1.73-100.

Pulleyblank, Edwin G. 1998. "Qièyùn and Yùnjìng: The essential foundation for Chinese historical linguistics". Journal of the American Oriental Society 118:2.200-216.

Sagart, Laurent. 1999. The Roots of Old Chinese. Amsterdam: John Benjamins.

Schuessler, Axel. 2006. "The Qièyùn system 'divisions' as the result of vowel warping". The Chinese Rime Tables ed. by David P. Branner, 83-96. Amsterdam: John Benjamins.

Schuessler, Axel. 2007. ABC Etymological Dictionary of Old Chinese. Honolulu: University of Hawai'i Press.

Shorto, Harry L. 1962. A Dictionary of Modern Spoken Mon. London: Oxford University Press.

Theraphan L. Thongkum. 1988. "Phonation types in Mon-Khmer languages". Vocal Physiology: Voice production, mechanisms and functions ed. by Osamu Fujimura. New York: Raven Press.

Yakhontov, Sergey E. 1986. "Shànggǔ Hànyǔ de Q̌̌shǒu Fǔyīn 1- hé r- [Initial 1- and r- in Old Chinese]”. Hànyǔ Shǐ Lùn Jí ed. by Táng Zuòfān [唐作藩] and Hú Shuāngbǎo [胡双宝], 156-165. Beijin: Beijin University Press. [First published in Russian 1976] 